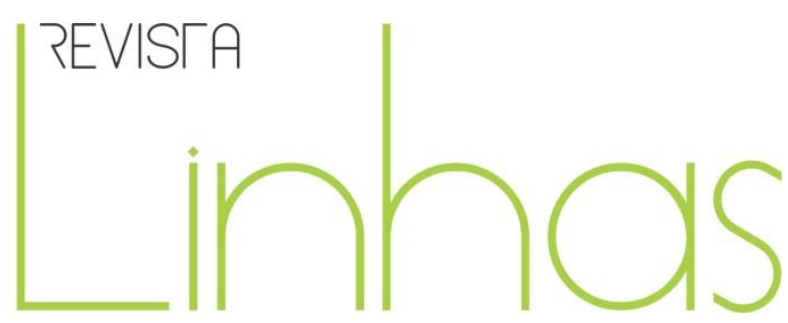

\title{
Do prescrito ao praticado: apropriações de materiais e métodos de ensino da leitura na escola primária de Santa Teresa (ES) na década de 1960
}

\section{Resumo}

Este artigo é parte da pesquisa realizada no mestrado e se ocupa em abordar apropriações que professores e alunos fizeram de materiais e métodos de ensino da leitura que circularam na escola primária de Santa Teresa (ES) na década de 1960. Trata-se de uma análise de natureza histórica seguindo princípios teórico-metodológicos da História Cultural, dialogando principalmente com Michel de Certeau e Roger Chartier, dentre outros autores que nos ajudaram a compreender a história do ensino da leitura na escola primária. Essas apropriações efetivadas a partir de práticas de ensino da leitura e da escrita foram materializadas em cadernos escolares e em provas parciais e finais realizadas pelos alunos, nos discursos inscritos em atas de reuniões pedagógicas, bem como em outros suportes de registros escolares que permitiram rastros dessa memória escolar teresense. O diálogo empreendido com essas fontes documentais possibilitou inferir que professores primários do município de Santa Teresa (ES) na década de 1960 se apropriavam de diferentes materiais e métodos por meio do uso de cartilhas, pré-livros e livros destinados à aprendizagem inicial da leitura, que desvelaram práticas de ensino que articularam princípios e métodos distintos a fim de atender às necessidades da escola primária. Desse modo, percebemos um distanciamento entre o discurso emanado por um órgão do Estado e a concretização do projeto educacional realizado.
Eliete Aparecida Locatelli Vago

Mestre em Educação pela

Universidade Federal do Espírito

Santo - UFES - Brasil elietevago@hotmail.com

Palavras-chave: Ensino primário; Santa Teresa (ES) - História; Leitura

- estudo e ensino.

\section{Para citar este artigo:}

VAGO, Eliete Aparecida Locatelli. Do prescrito ao praticado: apropriações de materiais e métodos de ensino da leitura na escola primária de Santa Teresa (ES) na década de 1960. Revista Linhas. Florianópolis, v. 16, n. 32, p. $357-390$, set./dez. 2015. 


\title{
From prescribed until practiced: appropriations of materials and methods of reading teaching in Santa Teresa Elementary School (ES) in the 1960 s
}

\begin{abstract}
This article is part of the research performed in Master and engages in addressing appropriations that teachers and students made of materials and methods of reading teaching that circulated in Santa Teresa Elementary School (ES) in the 1960s. This is an analysis of historical nature following theoretical and methodological principles of Cultural History, especially with Michel de Certeau and Roger Chartier dialogue, among other authors who have helped us understand the history of the teaching of reading in elementary school. These appropriations effect from practices of reading and writing teaching were materialized in school notebooks and in partial and final tests performed by students, in the speeches enrolled in minutes of meetings pedagogical, as well as in other supporters of school records that allowed traces of this Teresense school memory. The dialogue undertaken with these documentary sources made possible to infer that primary teachers in the municipality of Santa Teresa (ES) in the $1960 \mathrm{~s}$ appropriated different materials and methods through the use of booklets, pre - books and books for the initial learning of reading, which unveiled teaching practices that articulated principles and different methods to meet the needs of primary school. Thus we see a gap between the discourse emanating from a departament of the state and the realization of the educational project performed.
\end{abstract}

Keywords: Primary education; Santa Teresa (ES) -

History; Reading study and teaching. 
Esses estilos de ação intervêm num campo que os regula num primeiro nível [...], mas introduzem aí uma maneira de tirar partido dele, que obedece a outras regras e constitui como que um segundo nível imbricado no primeiro [...]. (CERTEAU, 1998, p. 92)

Pensar práticas de ensino da leitura que se configuraram na escola primária teresense na década de 1960 é pensar as “mil maneiras de 'fazer com"” e, desse modo, buscar por meio delas entender a complexidade que se constitui entre estratégias de prescrição de materiais e métodos por agentes responsáveis pelas políticas educacionais e apropriações desses materiais e métodos por professores e alunos no universo escolar.

Tomando por base esse princípio, neste artigo, que é parte da pesquisa realizada no mestrado, abordamos apropriações que professores e alunos fizeram de materiais e métodos de ensino da leitura que circularam na escola primária de Santa Teresa (ES) na referida década. Cabe destacar, que se trata de uma análise de natureza histórica seguindo princípios teórico-metodológicos da História Cultural, dialogando principalmente com Michel de Certeau e Roger Chartier, dentre outros autores que nos ajudaram a compreender a história do ensino da leitura na escola primária.

Carvalho (1998) ressalta que as práticas de apropriação definem comunidades distintas de usuários ${ }^{1}$ e configuram os usos que são feitos dos objetos e dos modelos culturais que lhes são impostos. Assim, buscamos abordar essas apropriações a partir de indícios de práticas de ensino efetivadas em sala de aula e materializadas em cadernos escolares, em provas finais e parciais realizadas pelos alunos. Além disso, nos pautamos em atas de reuniões pedagógicas das Escolas Reunidas "Patrimônio de Santo Antônio", que nos permitiram rastros dessa memória escolar teresense 2 .

\footnotetext{
1 Esclarecemos que o termo "usuários" foi tomado de Carvalho (1998) em seu texto intitulado "Por uma história cultural dos saberes pedagógicos".

2 A composição do acervo da pesquisa constitui-se em documentos guardados por alunos de escolas primárias teresenses da década de 1960, em documentos de arquivos públicos desativados, em arquivos de escolas primárias em funcionamento desde a época, bem como documentos levantados em visitas às instituições de guarda de documentação do Espírito Santo, que pudessem nos auxiliar na elucidação da nossa temática de estudo.
} 


\section{Materiais e métodos de ensino da leitura na escola primária de Santa Teresa}

(ES)

O propósito de refletirmos acerca dessas apropriações nos levou a atentar sobre aspectos da cultura escolar naquele espaço/tempo, pois, de acordo com Vidal (2005, p. 5, grifos do autor), a escola deve ser compreendida “[...] como um lugar de produção de uma cultura específica, em que constantemente atualizavam-se estratégias modeladoras $e$ táticas de subversão".

Tomamos o pensamento de Dominique Julia (2001) para reflexão sobre essa categoria, visto que o estudioso nos convida a retomarmos a "caixa-preta" da escola e interrogarmos sobre suas práticas cotidianas, sobre o seu funcionamento interno para maior compreensão do que interfere na/para constituição de práticas de ensino nesse espaço particular. Para Julia (2001 p. 10, grifos do autor), a cultura escolar refere-se a

[...] um conjunto de normas que definem conhecimentos a ensinar e condutas a inculcar, e um conjunto de práticas que permitem a transmissão desses conhecimentos e a incorporação desses comportamentos; normas e práticas coordenadas a finalidades que podem variar segundo as épocas (finalidades religiosas, sociopolíticas ou simplesmente de socialização).

Discorrer sobre a acepção de cultura escolar a partir das proposições desse autor é dar atenção às práticas, aos aspectos internos da escola e suas relações cotidianas engendradas em cada período de sua história. Assim, entendemos que não podemos abordar o ensino da leitura em Santa Teresa (ES) sem considerarmos apropriações de professores e alunos que eram chamados a obedecerem normas, prescrições, orientações em relação à utilização de materiais e métodos inculcados para tal fim.

Nesse âmbito, interessou-nos conhecer aspectos concernentes à cultura escolar teresense na época em questão, a fim de identificarmos pistas que pudessem contribuir para a compreensão de articulações entre materiais e métodos que estavam sendo divulgados como adequados, através da política educacional vigente, e formas de uso desses materiais e métodos. Para isso, apoiamo-nos em Certeau (1998), mais especificamente na discussão sobre o "homem ordinário", que ocupa o centro de nossa 
"cena científica"”, pois nossa atenção se volta às pessoas que habitaram o cotidiano da escola primária de Santa Teresa (ES) para flagrar nas práticas educativas nuances sobre o ensino da leitura.

Tomamos de Chartier (2002) a concepção de apropriação compreendida como possibilidade de diferentes usos de um determinado objeto ou prática. Partindo desse princípio, inicialmente, analisamos cadernos escolares que representam e materializam momentos de práticas culturais escolares experimentadas e vivenciadas pelos professores e alunos da escola primária teresense na década de 1960.

Sobre o uso de cadernos escolares como fontes históricas, Viñao (2008, p. 22) esclarece que "[...] é um instrumento fundamental para nos aproximar dos tempos (ritmos, sequências, momentos) reais da atividade escolar". Os cadernos que recuperamos contemplaram atividades sobre a leitura do $1^{\circ}, 2^{\circ}$ e $4^{\circ}$ anos primários recolhidos em arquivos pessoais cedidos para essa pesquisa ${ }^{4}$.

Temos consciência de que esses exemplares não representam todas as atividades produzidas pelos alunos em sala de aula, pois, como ressaltou Viñao (2008, p. 25), “nem tudo está nos cadernos", assim, boa parte das atividades que envolviam a leitura não nos foi permitido conhecer. No entanto, o que consta nos cadernos levantados se colocou como pertinente aos objetivos da pesquisa.

Conforme discriminação feita na tabela abaixo, nossa análise se atém a oito cadernos de alunos, sendo três cadernos do primeiro ano, três do segundo ano e dois do quarto ano primário. Cabe salientar, também, que não conseguimos recuperar exemplares do terceiro ano primário referente à década, cujas atividades contemplassem a leitura, critério utilizado para a seleção dessa fonte documental.

\footnotetext{
3 Salientamos que as expressões "homem ordinário" e "cena científica" foram tomadas de Michel de Certeau (1998, p. 57) e ilustram a participação de alunos e professores primários que se tornaram protagonistas desta pesquisa ao disponibilizarem documentos que representam e materializam práticas culturais de escolas primárias teresenses da época.

4 Os cadernos contemplados na análise nos aproximaram das práticas escolares de três escolas singulares do município, por isso, consideramos que são amostras das atividades pedagógicas que eram realizadas nas salas de aulas do município de Santa Teresa (ES) no decorrer da década em estudo.
} 
Tabela 01 - Distribuição do acervo documental de cadernos escolares utilizados para análise

\begin{tabular}{|c|c|c|}
\hline Tipo de fonte documental & Ano & Descritivo \\
\hline $\begin{array}{l}\text { Caderno de Aluno } \\
\text { (Linguagem) }\end{array}$ & 1960 & $\begin{array}{l}1^{\circ} \text { ano - Classe } A-\text { Atividades de 06/08/1960 até } \\
\text { 31/08/1960 }\end{array}$ \\
\hline Caderno de aluno & 1960 & $\begin{array}{l}1^{\circ} \text { ano - Classe A - Atividades de } 11 / 08 / 1960 \text { até } \\
24 / 10 / 1960\end{array}$ \\
\hline Caderno de aluno & 1966 & $\begin{array}{c}1^{\circ} \text { ano - Classe A - Esse exemplar não possui } \\
\text { discriminação do período de realização das atividades, } \\
\text { no entanto, temos conhecimento do ano pela análise do } \\
\text { certificado de conclusão do } 4^{\circ} \text { ano do aluno }\end{array}$ \\
\hline Caderno de aluno & 1968 & $2^{\circ}$ ano \\
\hline $\begin{array}{l}\text { Caderno de aluno (dever de } \\
\text { casa) }\end{array}$ & 1969 & $2^{\circ}$ ano \\
\hline Caderno de aluno & 1969 & $2^{\circ}$ ano \\
\hline Caderno de aluno & 1961 & $4^{\circ}$ ano \\
\hline Caderno de aluno & 1964 & $4^{\circ}$ ano - Atividades de 07/04/1964 até $12 / 05 / 1964$ \\
\hline
\end{tabular}

Nota: Tabela elaborada pela autora a partir dos cadernos analisados.

As atividades contidas nos cadernos revelam a "[...] singularidade desses textos que se dão a conhecer da maneira mais clara e mais completa as ideias partilhadas" (CHARTIER, 2002, p. 48). Sendo assim, essas atividades/textos possibilitaram apontar tendências indicadoras do uso de diferentes métodos de ensino da leitura pelos professores da escola primária no contexto investigado.

Para uma maior compreensão de formas de usos desses métodos pelos professores, identificamos quais as atividades mais recorrentes nos cadernos e as organizamos por categorias. Na tabela 2, apresentamos uma síntese das ocorrências dessas atividades, que permitiu constatar a recorrência da cópia, do ditado, da produção de frases, e ainda outras atividades 5 que contemplavam a leitura e a escrita.

Tabela 02 - Síntese das ocorrências de atividades que contemplaram o trabalho com a leitura/escrita nos cadernos escolares

\begin{tabular}{lll}
\hline Atividades & Série & Ocorrências \\
\hline Escrita das letras do alfabeto: vogais e consoantes & $1^{\circ}$ Ano & 34 \\
\hline Cópia de sílabas & $1^{\circ}$ Ano & 14 \\
\hline Cópia de palavras & $1^{\circ}$ Ano & 20 \\
\hline
\end{tabular}

5 Referimo-nos a atividades como: leitura silenciosa de textos, leitura de frases e palavras, produção de textos, interpretação de textos, além de atividades que envolviam aspectos gramaticais. 


\begin{tabular}{|c|c|c|}
\hline Cópia de frases & $1^{\circ} \mathrm{Ano} / 2^{\circ}$ Ano & 52 \\
\hline Cópia de textos & $\begin{array}{c}1^{\circ} \text { Ano } \\
2^{\circ} \text { Ano } / 4^{\circ} \text { Ano }\end{array}$ & 71 \\
\hline Cópia do nome do aluno & $1^{\circ}$ Ano & 39 \\
\hline Cópia do nome da mãe do aluno & $1^{\circ} \mathrm{Ano}$ & 1 \\
\hline Cópia do nome da professora & $1^{\circ} \mathrm{Ano}$ & 8 \\
\hline Ditado de palavras & $1^{\circ} \mathrm{Ano} / 2^{\circ} \mathrm{Ano}$ & 4 \\
\hline Ditado de frases & $2^{\circ}$ Ano & 1 \\
\hline Ditado de textos & $2^{\circ} \mathrm{Ano} / 4^{\circ}$ Ano & 26 \\
\hline Leitura silenciosa de textos & $2^{\circ} \mathrm{Ano} / 4^{\circ} \mathrm{Ano}$ & 4 \\
\hline Leitura silenciosa de textos (adivinhação) & $1^{\circ}$ Ano & 1 \\
\hline Leitura de palavras & $1^{\circ}$ Ano & 1 \\
\hline Leitura/cópia de palavras & $1^{\circ} \mathrm{Ano}$ & 1 \\
\hline Redação & $4^{\circ}$ Ano & 3 \\
\hline Produção de frases a partir de palavras & $1^{\circ} \mathrm{Ano} / 2^{\circ} \mathrm{Ano}$ & 5 \\
\hline Produção de frases a partir de imagem & $1^{\circ}$ Ano & 10 \\
\hline Produção de textos (a partir de palavras, imagens) & $2^{\circ}$ Ano $/ 4^{\circ}$ Ano & 12 \\
\hline $\begin{array}{l}\text { Produção de textos (carta, convite, bilhete, telegrama, } \\
\text { recibo, etc.) }\end{array}$ & $2^{\circ} \mathrm{Ano} / 4^{\circ} \mathrm{Ano}$ & 16 \\
\hline Interpretação de textos & $2^{\circ} \mathrm{Ano} / 4^{\circ} \mathrm{Ano}$ & 10 \\
\hline Ligar palavras & $1^{\circ}$ Ano & 2 \\
\hline Completar palavras com sílabas & $1^{\circ} \mathrm{Ano} / 2^{\circ} \mathrm{Ano}$ & 2 \\
\hline $\begin{array}{l}\text { Escrita de palavras a partir de letras iniciais indicadas } \\
\text { pelo professor }\end{array}$ & $1^{\circ} \mathrm{Ano} / 2^{\circ} \mathrm{Ano}$ & 3 \\
\hline Escrita de palavras a partir da indicação do professor & $2^{\circ}$ Ano & 2 \\
\hline Separação de sílabas & $1^{\circ} \mathrm{Ano}$ & 5 \\
\hline Historieta & $4^{\circ}$ Ano & 1 \\
\hline $\begin{array}{l}\text { Aspectos gramaticais: classes de palavras, uso do m ou } \\
\mathrm{n} \text {, vogais e consoantes, sílaba tônica, acentuação, } \\
\text { masculino/ feminino, plural/singular, } \\
\text { aumentativo/diminutivo, sinais de pontuação, análise } \\
\text { sintática, etc. }\end{array}$ & $\begin{array}{c}1^{\circ} \mathrm{Ano} \\
2^{\circ} \mathrm{Ano} / 4^{\circ} \text { Ano }\end{array}$ & 99 \\
\hline
\end{tabular}

Como anunciamos anteriormente, os impressos de destinação pedagógica ${ }^{6}$, como livros, boletins, orientações que partiam da Secretaria de Educação e de diretoras e supervisoras escolares para subsidiar o trabalho com o ensino da leitura nas escolas primárias na década em estudo, apresentavam defesa do ensino globalizado, da integração dos conteúdos, do uso de recursos audiovisuais e do método global. A tônica dessas defesas era fundamentada em princípios do pensamento renovador predominante do ideário escolanovista.

6 Cabe salientar que tomamos a expressão "impressos de destinação pedagógica" a partir da concepção de Carvalho (1998). 
No entanto, notamos, nos cadernos de aluno da primeira série, a presença de atividades que se contrapõem à aposta da política educacional que julgava o método global como mais adequado para o ensino da leitura. As atividades de escrita constantes nos cadernos que fizeram parte do corpus documental do estudo evidenciam que os professores se apropriavam de vários métodos de ensino, conforme pode ser observado nas figuras a seguir:

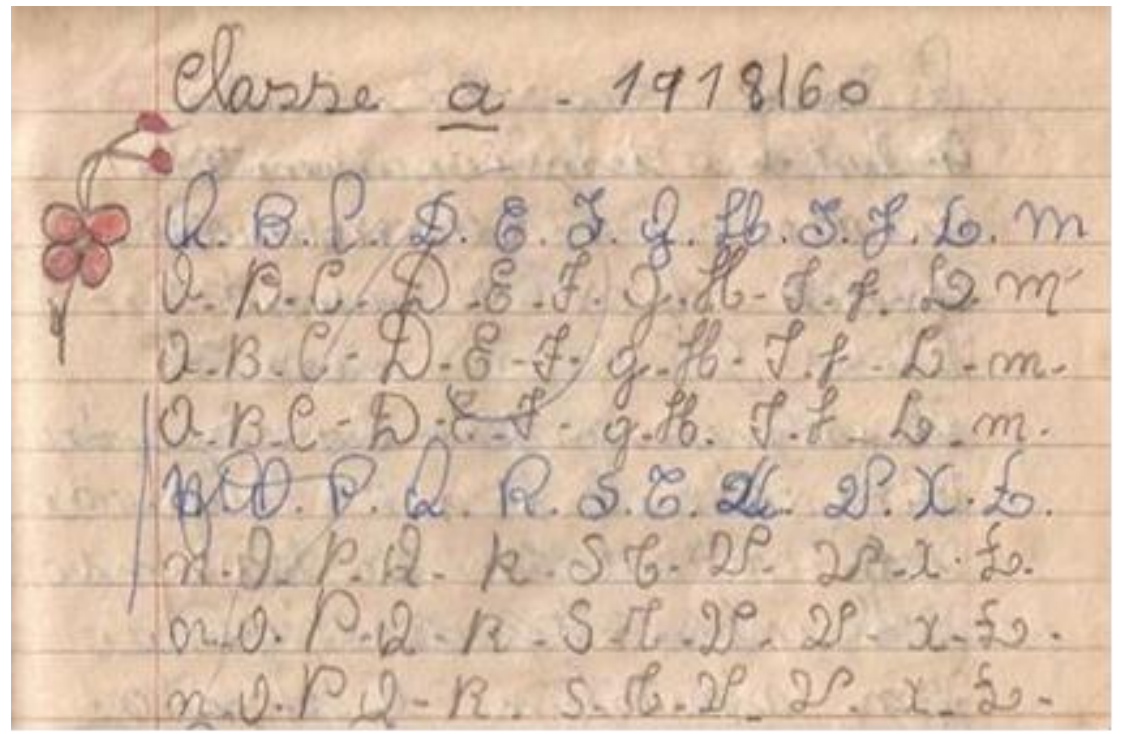

Figura 1: Fragmento do caderno da aluna do primeiro ano "A" da Escola Singular

"Baixo Santa Júlia".

Atividade realizada em 19/08/1960.

Fonte: Arquivo pessoal de Maria de Fátima Melotti.

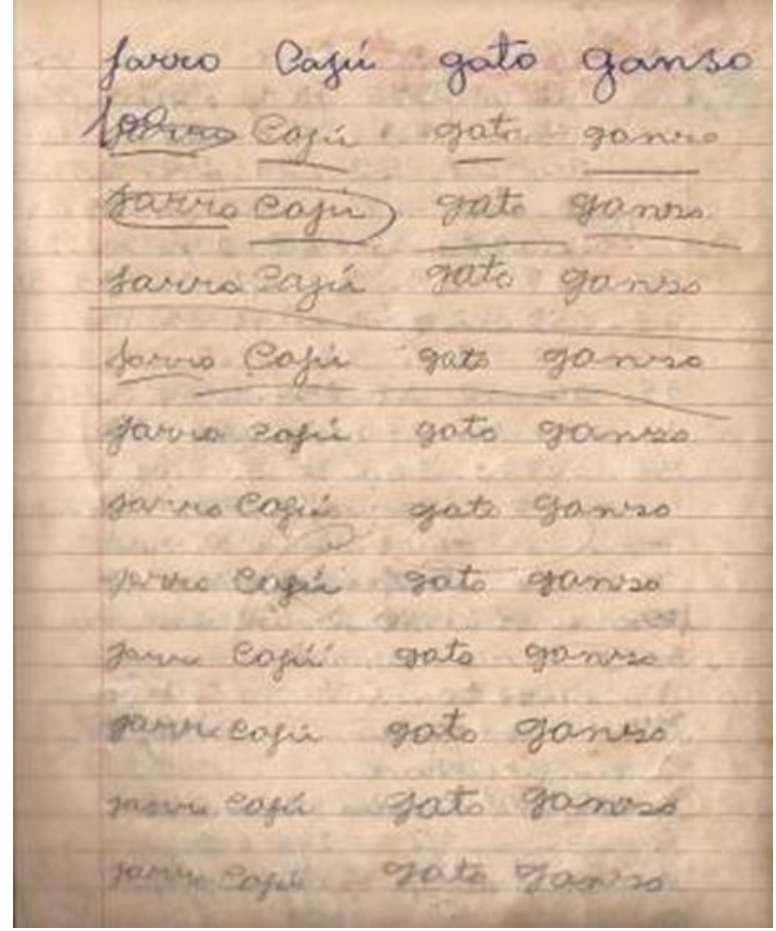

Figura 2: Fragmento do caderno da aluna do primeiro ano "A" da Escola Singular "Baixo Santa Júlia". Atividade realizada 1960.

Fonte: Arquivo pessoal de Maria de Fátima Melotti.

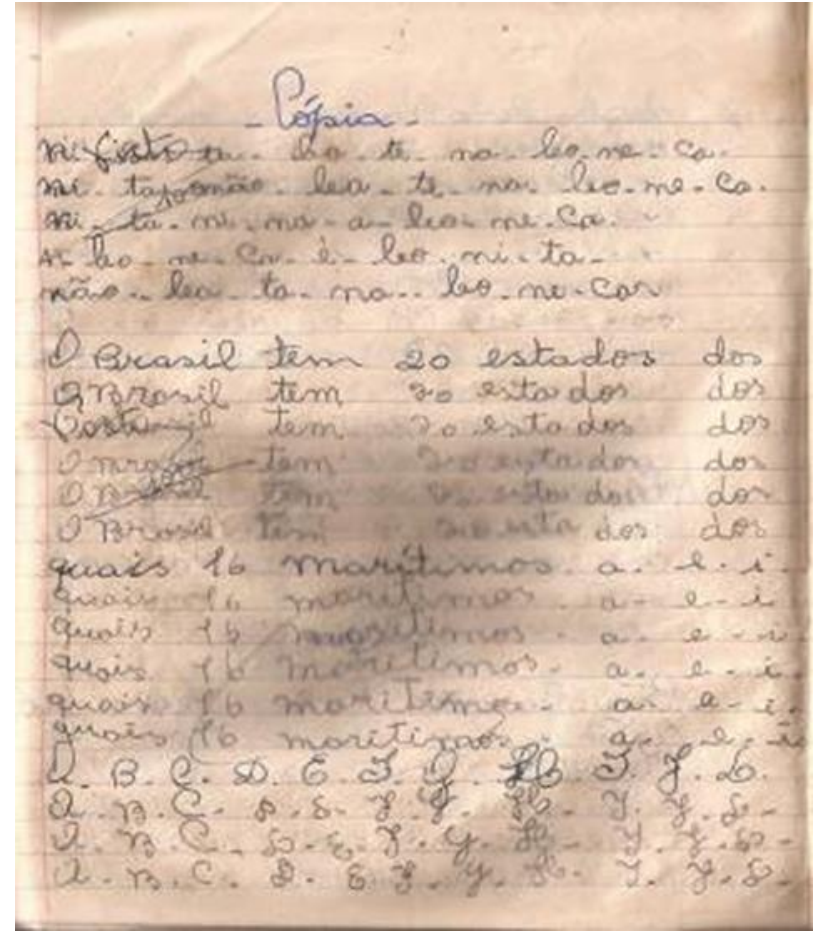

Figura 3: Fragmento do caderno da aluna do primeiro ano " $A$ " da Escola Singular "Baixo Santa Júlia". Atividade realizada em1960.

Fonte: Arquivo pessoal de Maria de Lurdes Milli. 
Os cadernos mostram atividades que indiciam práticas de ensino respaldadas por uma visão mecanicista em que se acredita que a aprendizagem da linguagem escrita deve enfatizar o ensino das letras do alfabeto, de palavras e frases isoladas. Nesse sentido, parece que, naquele momento da história do município Santa Teresa (ES), o ensino primário era perpassado por práticas que valorizavam a marcha que vai das partes para o todo e que privilegiavam a memorização de sinais gráficos. É recorrente nos cadernos atividades de separação de palavras e frases em sílabas, o que insinua que o tratamento de correspondências fonográficas podia estar seguindo também preceitos de variações de métodos silábicos.

Pelas atividades, pode-se inferir ainda que o conhecimento das letras do alfabeto e de palavras e frases isoladas era trabalhado por meio da memorização e da repetição. Isso se visualiza nos cadernos a partir de atividades de escrita que priorizavam a caligrafia, a cópia, mostrando a ênfase na ortografia e no desenho correto de letras e de palavras.

Vale lembrar que Frade (2007, p. 25) alerta que

os métodos sintéticos, em geral, parecem privilegiar o sentido do ouvido na relação com os sinais gráficos e neles eram comuns os exercícios de leitura em voz alta e o ditado: todas estas atividades guardam coerência com um tipo de pressuposto: o da transformação da fala em sinais gráficos.

Assim, partindo do princípio que fundamenta a afirmação de Frade (2007), podemos notar apropriações de princípios de variações do método sintético para o ensino da leitura por parte dos professores das escolas primárias teresenses na década de 1960. Os cadernos mostram que era efetiva e contínua a atividade de ditado com os alunos conforme as ilustrações a seguir: 


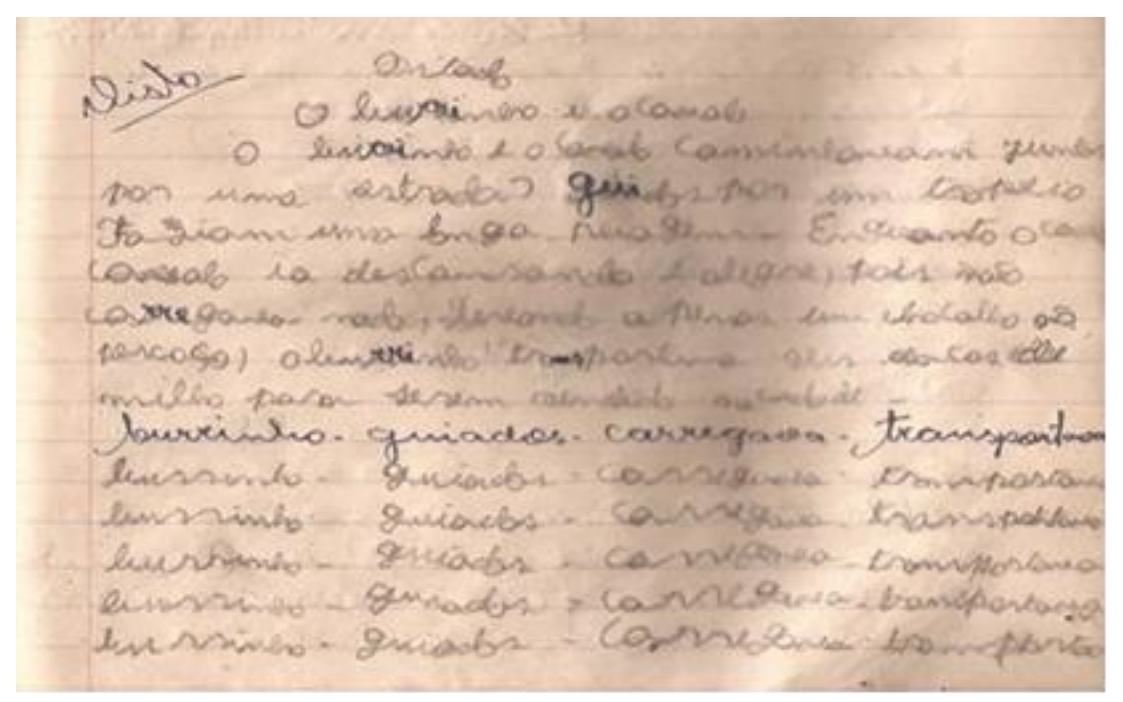

Figura 4: Fragmento do caderno da aluna do segundo ano da Escola Singular "São Dalmácio".

Atividade realizada em 1968. Fonte: Arquivo pessoal de Dimas Filipini.

Assim como a cópia, o ditado era uma atividade privilegiada na época e se apresentava como textos de assuntos e extensão variados. Os textos serviam para identificar problemas ortográficos, que eram trabalhados por meio de cópia da grafia correta das palavras. Era aplicado com maior intensidade nas séries do segundo ao quarto ano. Vale destacar que os professores, de acordo com as atas de reuniões pedagógicas, eram orientados a dar o ditado das palavras que os alunos tivessem maiores dificuldades. Desse modo, entende-se que essa atividade tinha como finalidade verificar as dificuldades que persistiam na escrita cotidiana do aluno, além de servir como treino e memorização da grafia correta da palavra, conforme podemos evidenciar na atividade da figura 4. Essas atividades parecem indicar tendências de apropriações de princípios de métodos analíticos para o ensino da leitura pelos professores da escola primária de Santa Teresa (ES).

A respeito dos métodos analíticos, Frade (2007, p. 29) nos esclarece que

de maneira, geral, pode-se dizer também que o sentido privilegiado nos métodos analíticos é a visão e que os principais exercícios envolvidos neste método voltam-se para o reconhecimento de palavras sem que se passe por uma leitura labial. Neles é muito incentivada a leitura silenciosa e a cópia e, embora se fizesse leitura oral dos cartazes no desenvolvimento das lições, era destinado um tempo maior para cópias. 
Nessa perspectiva, as figuras 5 e 6 ilustram atividades realizadas pelos alunos da escola primária, que denunciam também apropriações de princípios subjacentes a métodos analíticos.

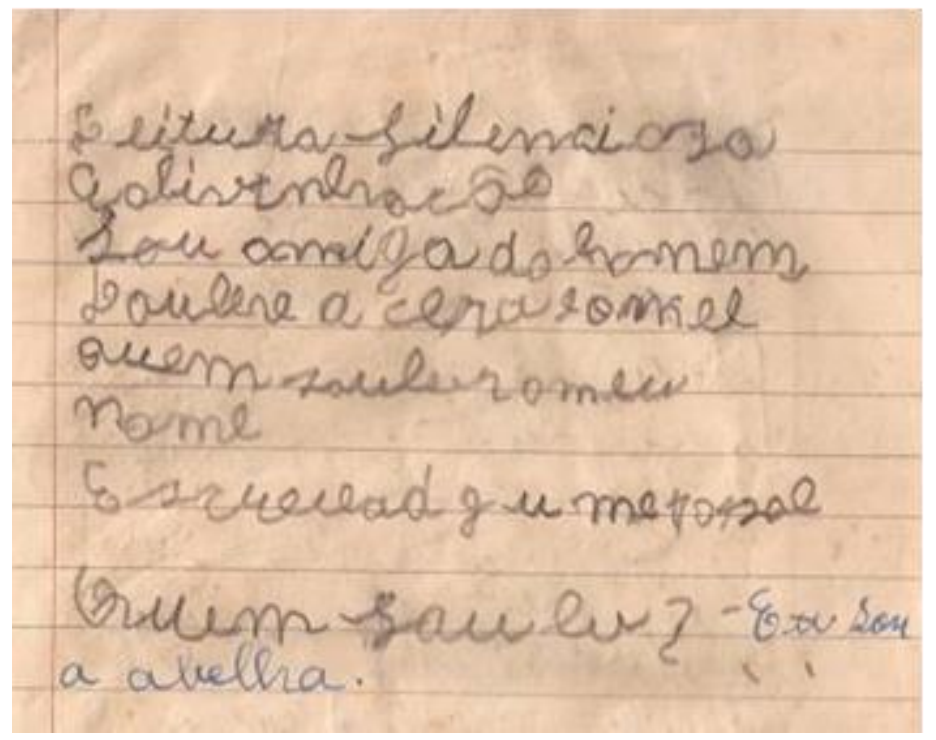

Figura 5: Fragmento do caderno do aluno do primeiro ano "A" da Escola Singular "Picadão do Mutum". Atividade realizada em 1966.

Fonte: Arquivo pessoal de Maria Alice Galon.

São atividades de cópia de pequenos textos que serviam para realização de leituras silenciosas pelos alunos e para responder a alguns questionamentos. Parecem, portanto, atividades que buscavam, de certa forma, trabalhar a compreensão também, visto que tomavam como ponto de partida uma unidade de significação.

Tais considerações podem indicar que, mesmo diante do discurso em defesa do método global por parte dos agentes educacionais responsáveis pelo ensino nas escolas primárias de Santa Teresa (ES) na década de 1960, os professores continuaram fazendo uso de atividades que se pautavam em princípios tanto de métodos de marcha analítica como sintética em suas práticas cotidianas. Dessa forma, é possível vislumbrar a coexistência de mais de uma tendência metodológica e de modos e formas de ensinar a ler na escola teresense. 


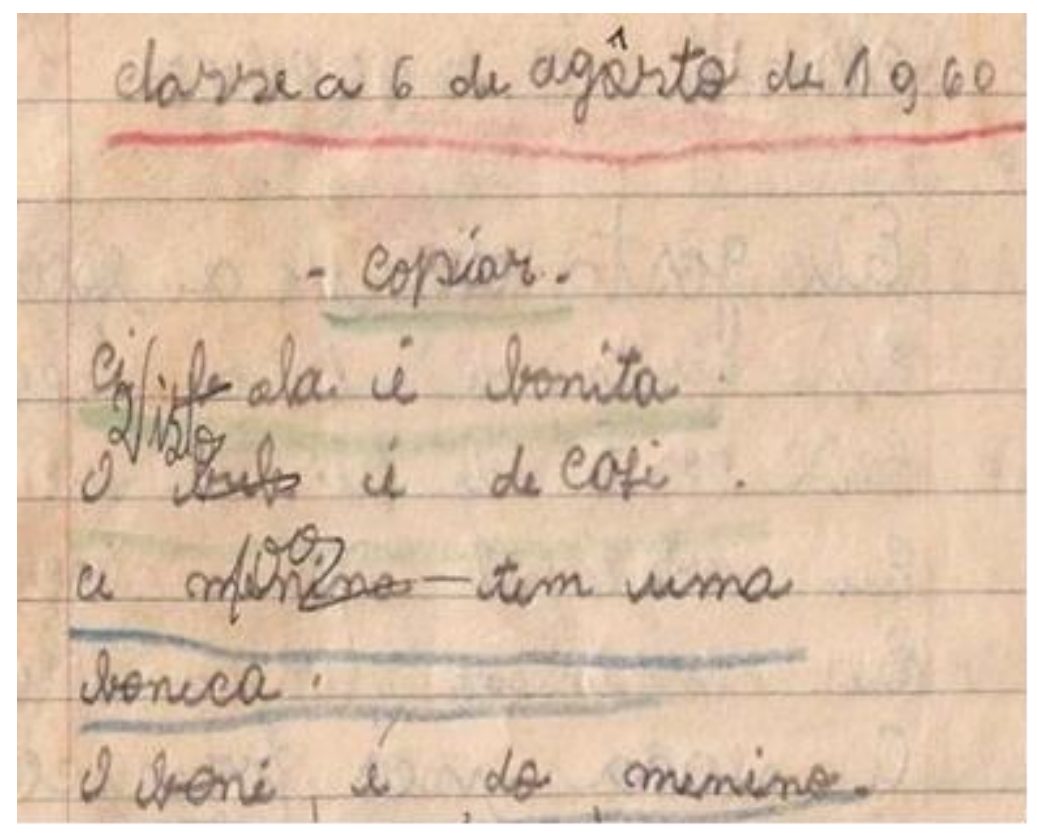

Figura 6: Fragmento do caderno da aluna do primeiro ano "A" da Escola Singular "Baixo Santa Júlia”. Atividade realizada em 06/08/1960 Fonte: Arquivo pessoal de Maria de Fátima Melotti.

Nesse sentido, as práticas de ensino da leitura parecem ser perpassadas por princípios que respaldam diferentes métodos de alfabetização, que foram se firmando historicamente como modelos de ensino da leitura e da escrita atravessados por tensões e disputas em torno do que era considerado como mais adequado para resolver os problemas de aprendizagem. De acordo com Mortatti (2008), as disputas serviram para fundar tradições em cada momento histórico. A autora alerta que

[...] se funda uma "nova tradição", centrada em um sentido que se tornou hegemônico, porque oficial, mas não único, nem homogêneo, nem tampouco isento de resistências, mediadas em especial pela velada utilização de antigos métodos e práticas alfabetizadoras, por meio da utilização de cartilhas, esse privilegiado e perene instrumento de concretização dos métodos de alfabetização. (MORTATTI, 2008, p. 95)

Baseando-nos em Mortatti (2008), é possível compreender que a constituição de práticas de ensino da leitura, na década de 1960, fundamentada em princípios de diferentes métodos, pode ter sido favorecida pelas possibilidades de escolhas e usos de cartilhas ou livros que circulavam e eram indicados para subsidiar o ensino inicial da leitura nas escolas primárias. 
Essa crença deve-se ao fato de termos identificado em Santa Teresa (ES) o uso de vários materiais voltados para o ensino da leitura que corroboram para afirmarmos a coexistência de princípios tanto de métodos analíticos como sintéticos. Identificamos usos, por exemplo, da Cartilha Ensino Rápido da Leitura, de autoria de Mariano de Oliveira, cuja capa é ilustrada na figura 7.

Mortatti (2000) esclarece que essa cartilha foi publicada, provavelmente, no início da década de 1920, tendo uma tiragem excepcional, atingindo no ano de 1965 um total de 1.134 edições. As palavras gravadas na página de rosto anunciavam sua circulação oficializada em estados brasileiros e dentre eles o Espírito Santo: “Approvada e adoptada officialmente no Estado de Sta. Catharina e adoptada no ensino do districto Federal, Espírito Santo, Paraná, Rio Grande do Norte e Piauhy” (MORTATTI, 2000, p. 102).

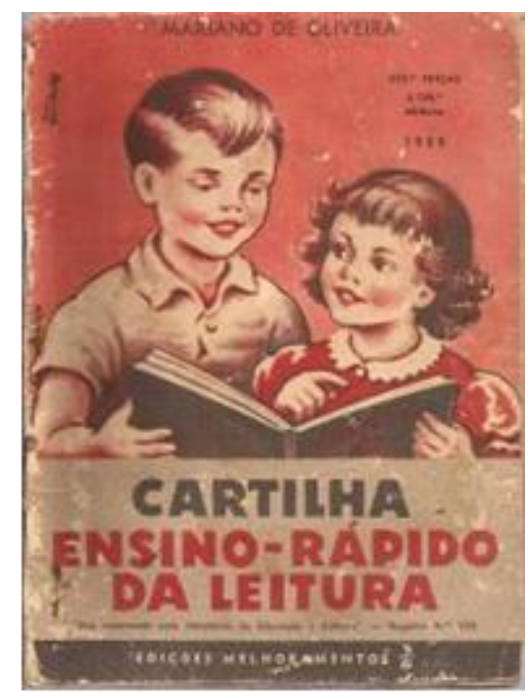

Figura 7: Capa da Cartilha Ensino Rápido da Leitura. Fonte: Arquivo pessoal de Lídia Torezani Bosi.

\begin{abstract}
Autor: OLIVEIRA, Mariano de
Título: Cartilha Ensino-Rápido da Leitura

Editora: Edições Melhoramentos

Ano: 1959

Edição: $820 .^{\text {a }}$ (edição revista)

Outras informações: Devido à dificuldade de ter acesso a edições da década de 1960, nesse caso, utilizamos um exemplar do ano de 1959. Nos casos em que pudemos comparar edições diferentes, notamos a manutenção do conteúdo e de sua abordagem.
\end{abstract}

De acordo com relatos feitos por alunos e professores que frequentaram a escola primária teresense na década de 1960, essa cartilha era popularmente conhecida por “Asa Ema”. Fato que se justifica, possivelmente, pela primeira lição da cartilha, conforme ilustra a figura 8. 


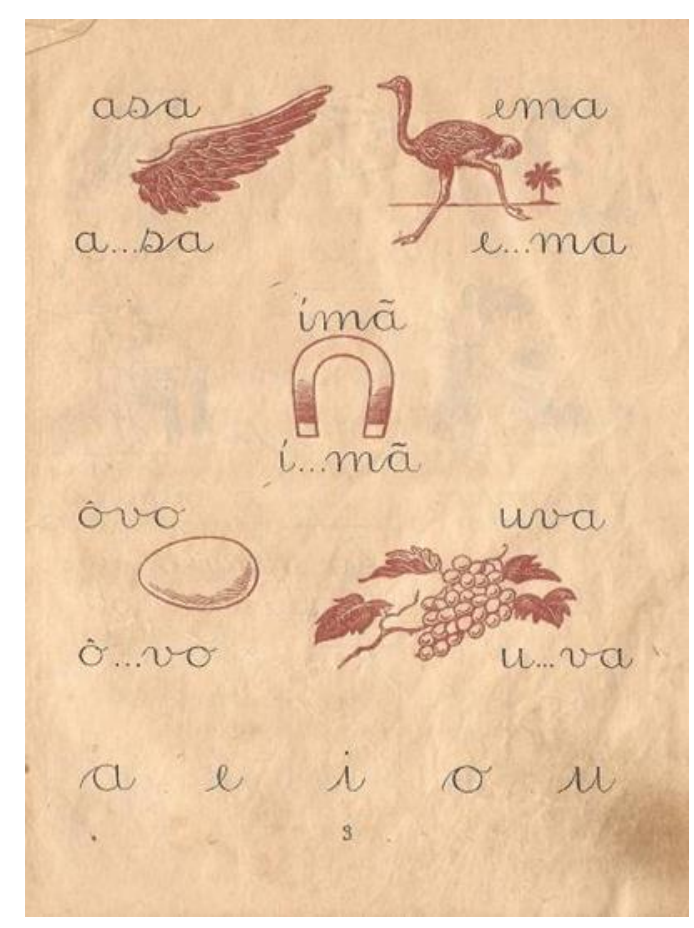

Figura 8: Primeira lição da Cartilha Ensino Rápido da Leitura, p. 3

Fonte: Arquivo pessoal de Lídia Torezani Bosi.

O uso dessa cartilha foi identificado inicialmente, na Escola Singular "Baixo Santa Júlia", em Santa Júlia, zona rural do município de Santa Teresa (ES), conforme podemos observar na atividade de cópia do texto da página 11, presente no caderno da aluna que cursava a primeira série “A" em 1960, como pode ser comprovado pelas figuras 9 e 10:

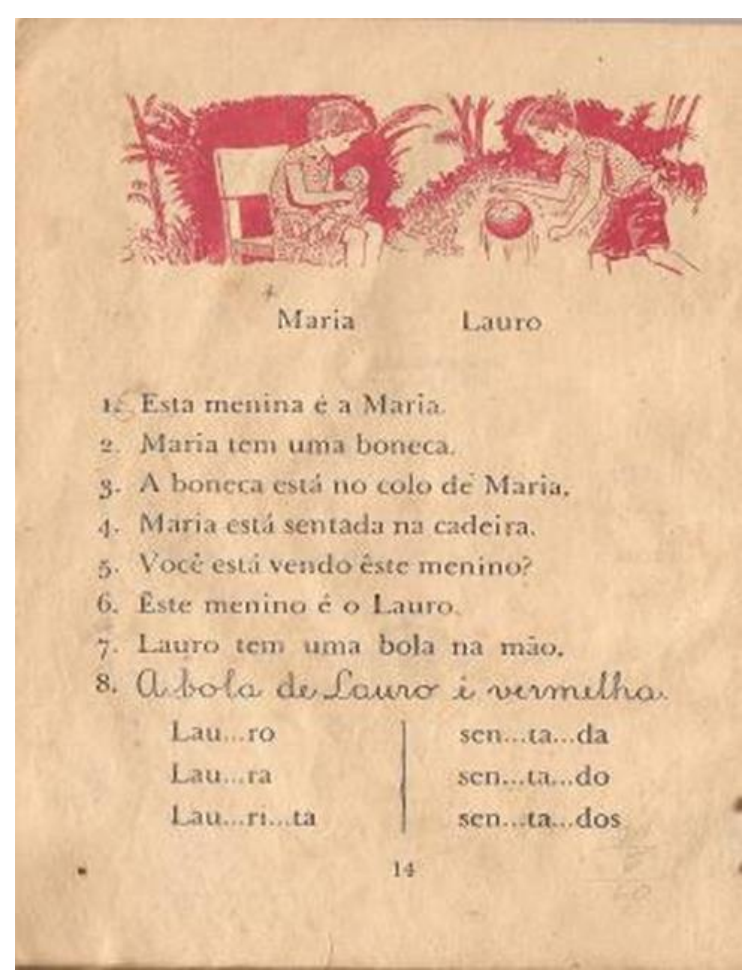

Figura 9: Página 14 da Cartilha do Ensino Rápido da Leitura.

Fonte: Arquivo pessoal de Lídia Torezani Bosi. 


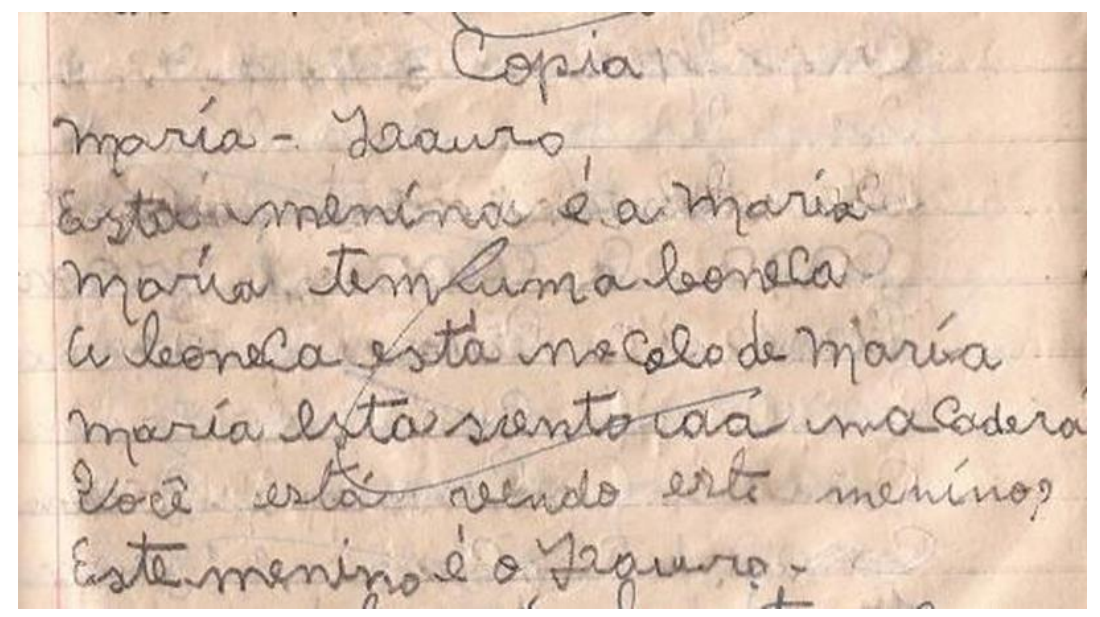

Figura 10: Fragmento do caderno da aluna do primeiro ano "A" da Escola Singular "Baixo Santa Júlia". Atividade realizada em: 29/08/1960. Fonte: Arquivo pessoal de Maria de Lurdes Milli.

Essa mesma cartilha foi utilizada na Escola Singular "Picadão de Mutum", no distrito de São João de Petrópolis, zona rural do município de Santa Teresa (ES) e com uso semelhante ao da Escola Singular "Baixo Santa Júlia", conforme observamos na atividade de cópia do texto da página 11 presente no caderno do aluno que cursava a primeira série no ano de 1966.

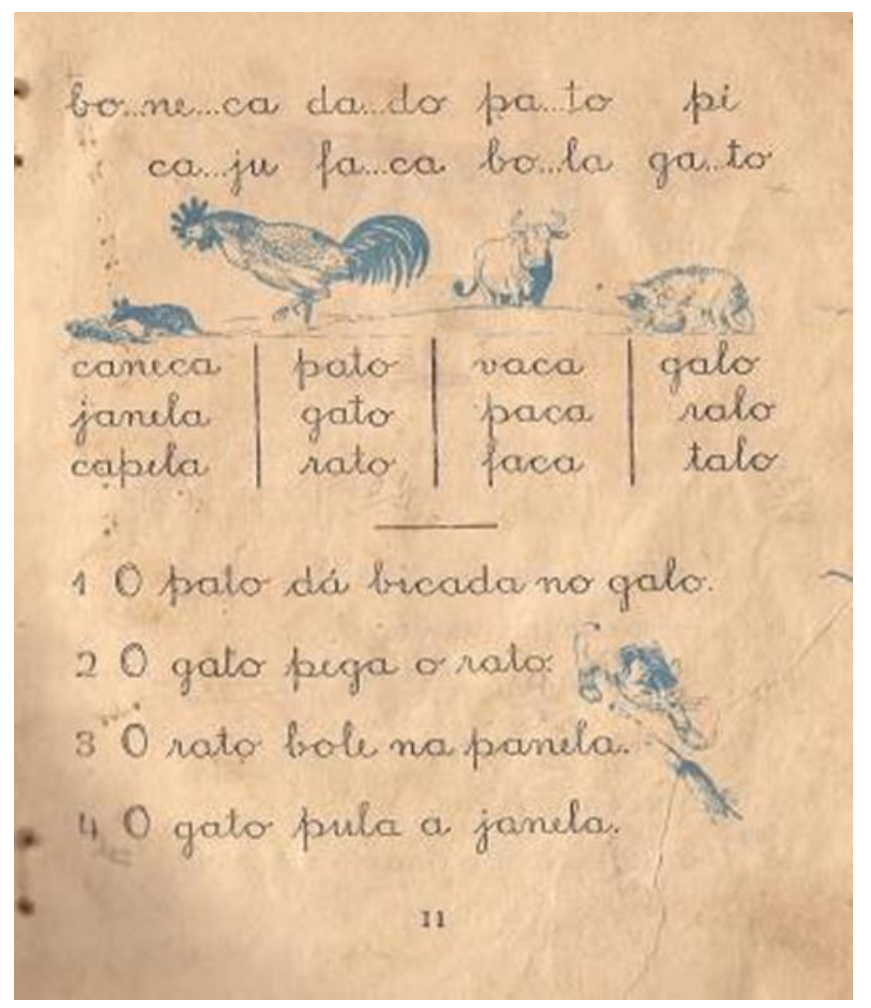

Figura 11: Página 11 da Cartilha Ensino Rápido da Leitura.

Fonte: Arquivo pessoal de Lídia Torezani Bosi. 


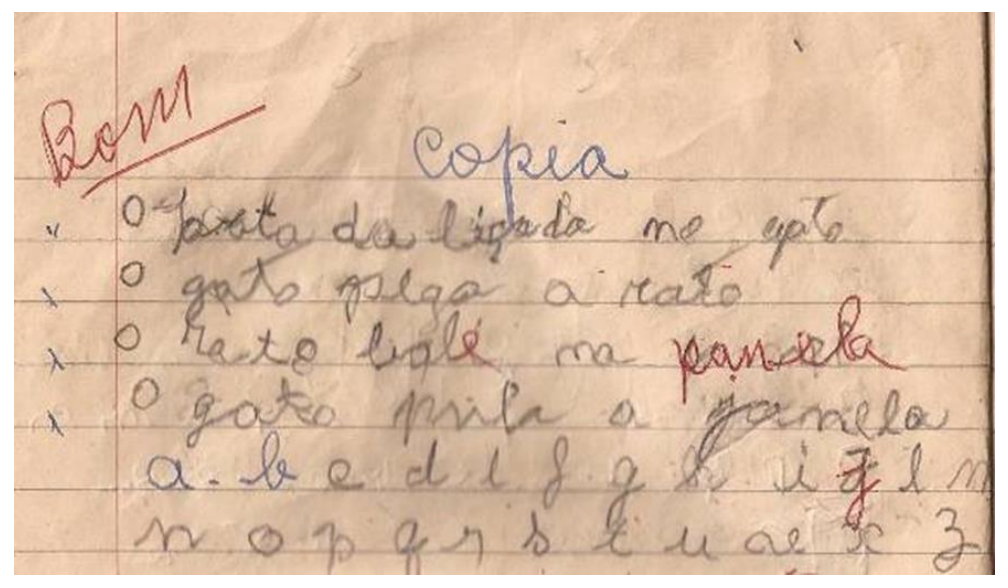

Figura 12: Fragmento do caderno do aluno do primeiro ano "A" da Escola Singular "Picadão do Mutum". Atividade em 1966 Fonte: Arquivo pessoal de Maria Alice Galon.

Segundo Gomes (2008), exemplares da cartilha de Mariano de Oliveira foram enviados, na década de 1920, a várias escolas do estado do Espírito Santo na tentativa de solucionar o problema da grande quantidade de alunos analfabetos. Em nossa investigação, averiguamos que a Cartilha Ensino Rápido da Leitura foi utilizada nas escolas primárias do município de Santa Teresa (ES) na década de 1960, conforme apropriações demonstradas. Isso nos leva à compreensão de que o uso da cartilha perdurou por décadas nas escolas primárias capixabas apontando a permanência da pedagogia tradicional em meio ao discurso renovador vigente no ensino primário da época.

As atividades contidas na cartilha demonstram a preocupação do autor em ensinar a leitura por meio de um método simples e rápido. As primeiras lições iniciavam-se com palavras sempre acompanhadas de estampas e redigidas em letra manuscrita vertical, separando-se em sílabas. Ao final da primeira lição são apresentadas as vogais, conforme ilustra a figura 8. As lições posteriores apresentavam palavras, divisão em sílabas e reorganização em frases, que são novamente separadas e divididas em sílabas. A letra de imprensa é apresentada a partir da página 12 e as historietas a partir da página 14. A cartilha é finalizada com a apresentação do alfabeto em letra de imprensa e manuscrita (MORTATTI, 2000).

Outro título encontrado com o propósito semelhante ao da cartilha anterior e utilizado paralelamente na escola primária teresense na mesma década foi a Cartilha do Povo: para ensinar a ler rapidamente, de autoria de Lourenço Filho, cuja capa é ilustrada na figura 13. 


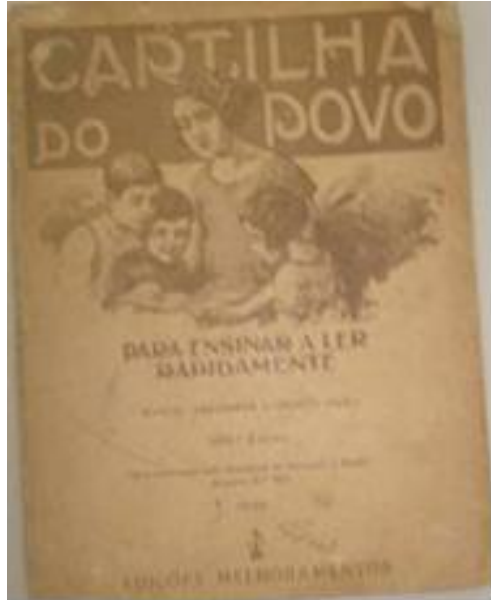

Autor: LORENÇO FILHO, Manuel Bergström

Título: Cartilha do Povo: para ensinar a ler rapidamente

Editora: Edições Melhoramentos

Ano: 1940

Edição: $586 .^{a}$

Outras informações: Devido à dificuldade de ter acesso a edições da década de 1960 , nesse caso, utilizamos um exemplar do ano de 1940. Nos casos em que pudemos comparar edições diferentes, notamos a manutenção do conteúdo e de sua abordagem.

Figura 13: Capa da Cartilha do Povo Fonte: Biblioteca FEUSP.

A Cartilha do Povo: para ensinar a ler rapidamente é parte de uma série de obras de Lourenço Filho, sendo sua primeira edição datada de 1928 e editada pela Companhia Melhoramentos. Segundo Mortatti (2000), a cartilha, durante muitas décadas, foi publicada sem o nome do autor e permaneceu em circulação por mais de meio século e com milhares de tiragens de edições sucessivas.

Ao compararmos a $8^{\text {a }}$ lição da Cartilha do Povo: para ensinar a ler rapidamente à atividade de cópia feita pela mesma aluna e no mesmo ano, no primeiro ano " $\mathrm{A}$ " podemos inferir que se trata de uma apropriação feita pelo professor de forma semelhante à da cartilha Ensino Rápido da Leitura, conforme mostram as figuras 14 e 15.

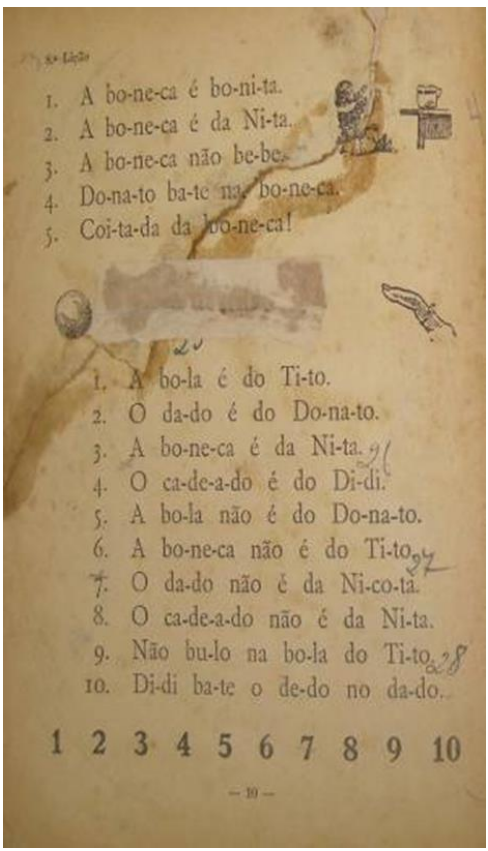
Fonte: Biblioteca FEUSP. 


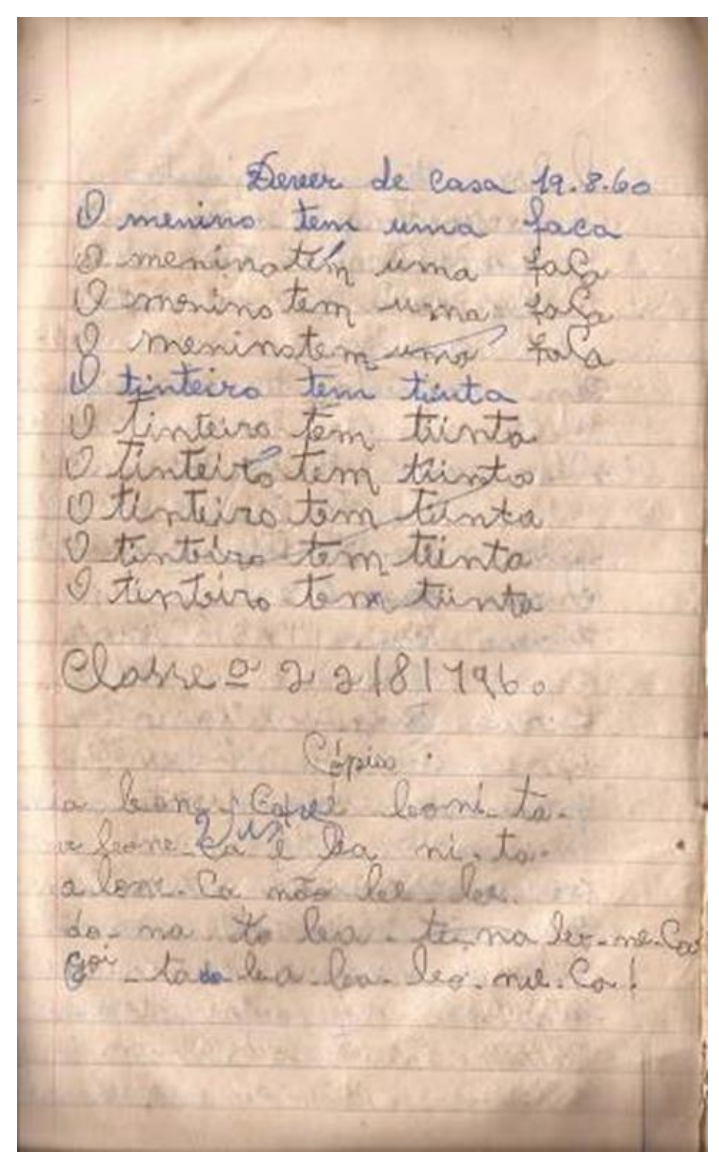

Figura 15: Fragmento do caderno da aluna do primeiro ano "A" da Escola Singular "Baixo Santa Júlia" Atividade realizada em: 22/08/1960 Fonte: Arquivo pessoal de Maria de Lurdes Milli.

A Cartilha do Povo: para ensinar a ler rapidamente é iniciada com a apresentação das vogais, conforme podemos observar na figura 16 e a partir da terceira lição são introduzidas as consoantes. As lições iniciais apresentavam uma ilustração, um vocábulo correspondente em tipo grande e com negrito, sílabas correspondentes ao vocábulo, novos vocábulos formados por diferentes combinações com as sílabas aprendidas e frases numeradas formadas com os vocábulos estudados, sempre fazendo o uso da letra de imprensa. Nas lições posteriores são apresentadas as sílabas complexas, e a divisão das sílabas com um hífen que predominava nas primeiras lições, desaparece. A cartilha apresenta nas suas lições finais o alfabeto em letra cursiva e de imprensa e os dígrafos, sendo finalizada com quatro historietas (MORTATTI, 2000). 


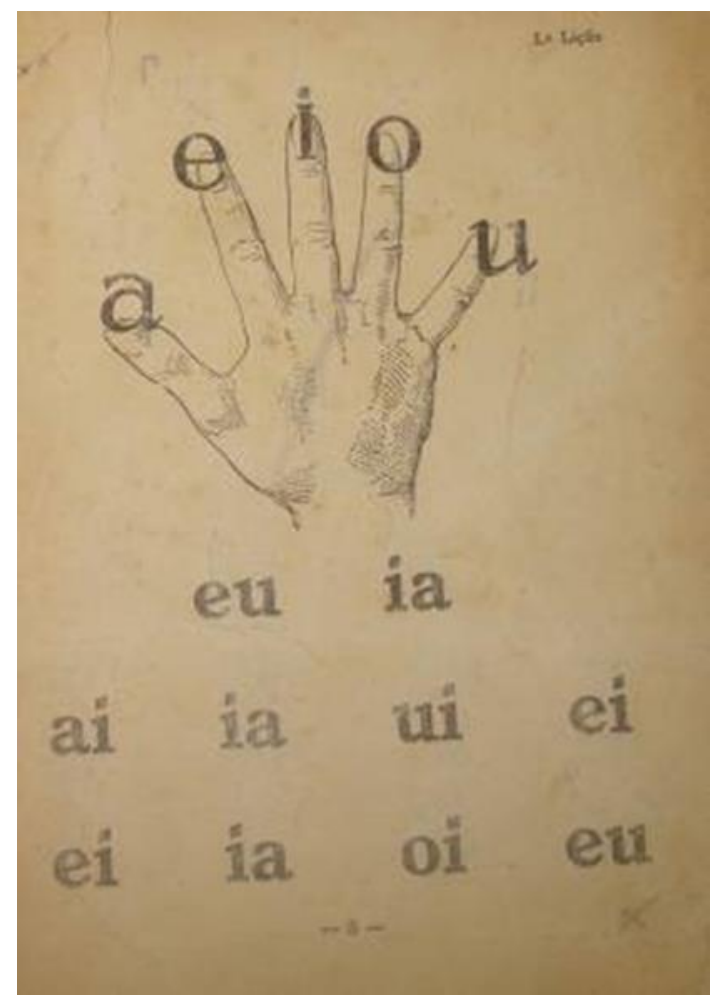

Figura 16: Primeira lição da Cartilha do Povo Fonte: Fonte: Biblioteca FEUSP.

Lourenço Filho considerava sua cartilha um material didático que poderia servir ao ensino tanto por meio de métodos sintéticos quanto pelos métodos analíticos. O autor assegurava que a cartilha poderia ser utilizada inclusive por leigos, devido à simplicidade de seu plano, além de ser um instrumento auxiliar de trabalho que tinha por finalidade a educação popular de crianças e adultos. As lições, de acordo com o autor, poderiam ser ensinadas pela silabação ou pela palavração, ficando à conveniência do uso de acordo com o professor (MORTATTI, 2000).

As primeiras lições da Cartilha Ensino Rápido da Leitura e da Cartilha do Povo: para ensinar a ler rapidamente evidenciam que o ensino inicial da leitura tomava como ponto de partida os constituintes menores (letras e sílabas) da língua, para os constituintes maiores (palavra, frase e texto). Sobre essa maneira de ensinar a leitura, Schwartz (2012, p. 23) pontua que

a aprendizagem da leitura nessa tendência é conduzida por um processo mecânico em que a criança aprende por repetição, por condicionamento, as unidades menores da língua com finalidade de memorizar padrões regulares de correspondências entre grafemas e fonemas, partindo sempre das unidades mais simples para as mais complexas. 
Nessa perspectiva, a utilização das duas cartilhas indicia apropriações de práticas de ensino da leitura que privilegiavam a decoração de sinais gráficos e as correspondências fonográficas que reduzem $\mathrm{o}$ ato de ler a mero processo de decodificação da linguagem escrita. Ou seja, entendemos que coexistiram propostas fundamentadas na concepção de linguagem que percebia a língua como um sistema fechado e autônomo, independente das orientações recebidas por parte da política educacional vigente que disseminavam o método global como mais apropriado para esse ensino (SCHWARTZ, 2012).

Em contrapartida, identificamos dentre os materiais utilizados pelos professores das escolas primárias de Santa Teresa (ES), a cartilha Onde está o patinho?, de Cecília Bueno dos Reis Amoroso; sua publicação ocorreu pela primeira vez em 1955 pela Editora Melhoramentos. Distinto dos títulos analisados anteriormente, essa cartilha apresentava uma proposta de ensino de leitura por meio de um conto cujas narrativas giravam em torno de experiências vivenciadas pelas crianças protagonistas em uma fazenda durante as férias. Conforme a autora, a história deveria atender ao interesse de ambos os sexos das crianças e concorrer, ao mesmo tempo, para a formação integral dos alunos.

A partir de 1972, essa cartilha passou a ser publicada pela Editora Lótus e apresentava as co-autoras Arminda Bueno dos Reis Amoroso e Angela Maria Bueno dos Reis Amoroso. Nessa edição, o formato e o conteúdo sofreram alterações, além de ter sido incorporado a ela um Manual do Professor. Suas edições seguintes passaram a ser publicadas pela Editora Saraiva?.

A figura 17 ilustra a capa da cartilha Onde está o patinho?

7 As informações correspondentes à cartilha e referentes ao parágrafo estão disponíveis em: <http://www.crmariocovas.sp.gov.br/obj_a.php?t=cartilhaso2>. Acesso em: 5 out. 2012. 


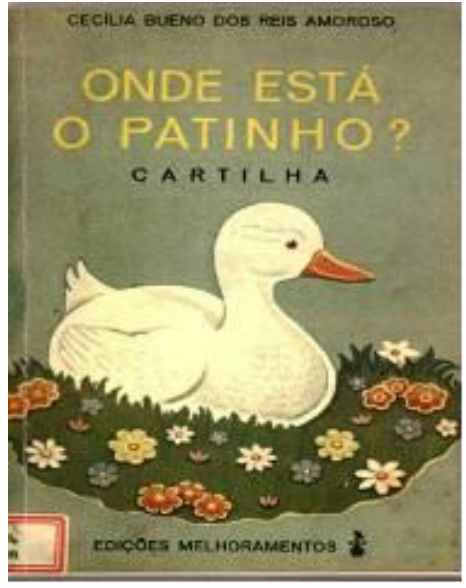

Figura 17: Capa da cartilha Onde está o patinho? Fonte: Biblioteca FEUSP.
Autor: AMOROSO, Cecília Bueno dos Reis

Título: Onde está o patinho?

Editora: Edições Melhoramentos

Ano:

Edição: -

Outras informações: O exemplar analisado nessa investigação pertence à Biblioteca FEUSP e não consta o ano e a edição. Nos casos em que pudemos comparar edições diferentes, notamos a manutenção do conteúdo e de sua abordagem.

A cartilha Onde está o Patinho? adotava o método da historieta e trazia orientações destinadas ao professor nas primeiras e últimas páginas. Essas orientações direcionavam o ensino da leitura proposto a partir da contação de uma história seguindo os critérios de fases. Na primeira fase, o professor deveria trabalhar as sentenças com destaque das palavras temas que apareciam sempre acompanhadas das figuras que movimentavam a historieta e lembravam o fonema relativo a uma letra para melhor fixação da palavra tema. Na segunda fase, o professor deveria trabalhar com a palavra tema com destaque da sílaba inicial através de exercícios. Em seguida, na terceira fase deveria ocorrer a mudança de vogal da sílaba tema, quando o professor era orientado para trabalhar com palavras conhecidas pelas crianças e sempre destacando qualquer sílaba nova. Na quarta e última fase, as letras simbolizavam crianças que falavam e se combinavam entre si como artifício facilitador do domínio das sílabas com novas dificuldades.

As lições dessa cartilha não se preocupavam com a apresentação ou sistematização de letras e sílabas no início do processo. O trabalho com os constituintes menores da língua iam ocorrendo ao longo dos exercícios propostos na última fase da alfabetização. As lições eram sempre acompanhadas de desenhos bastante simples para que, segundo a autora, as crianças pudessem compreendê-los e copiá-los com facilidade e prazer.

O uso dessa cartilha no ensino primário de Santa Teresa (ES) foi constatado na Escola Singular “Baixo Santa Júlia” em 1960. A apropriação feita pelo professor e 
materializada no caderno de uma aluna do primeiro ano " $A$ " atesta a presença desse material como subsídio ao ensino inicial da leitura no município. No entanto, desvela uso semelhante ao das cartilhas apresentadas anteriormente, com a realização da atividade de cópia do texto da página 11 feita no caderno da aluna. As figuras 18 e 19 confirmam essa apropriação:

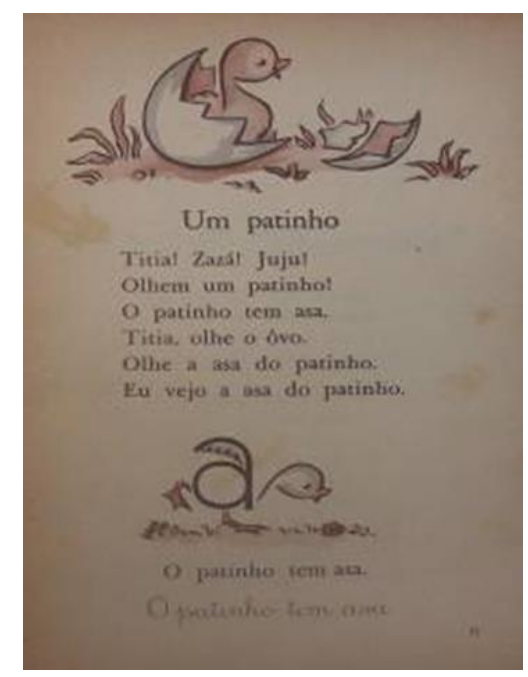

Figura 18: Lição da cartilha Onde está o patinho?

Fonte: Biblioteca FEUSP.

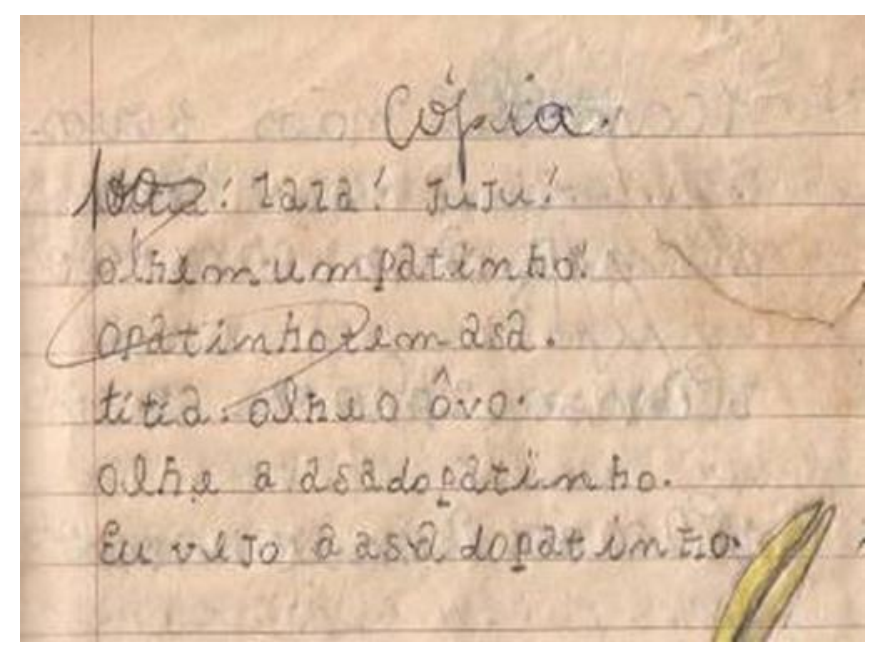

Figura 19: Fragmento do caderno da aluna do primeiro ano "A" da Escola Singular "Baixo Santa Júlia". Atividade realizada em 17/08/1960.

Fonte: Arquivo pessoal de Maria de Fátima Melotti.

É interessante notar que, a julgar pelas atividades registradas nos cadernos escolares das alunas, deparamo-nos, em uma mesma escola, com o uso concomitante de textos de três cartilhas diferentes para o ensino inicial da leitura no ano de 1960. As cartilhas Cartilha Ensino Rápido da Leitura (Asa Ema) e a Cartilha do povo apresentavam fundamentos do método sintético, apesar de Lourenço Filho alegar que a Cartilha do Povo pudesse ser utilizada tanto pelo método sintético quanto pelo analítico, e a Cartilha onde está o patinho?, fundamentos do método analítico; essas apropriações feitas pelo professor indiciam o uso de diferentes métodos e materiais didáticos nas práticas do ensino da leitura.

Nesse sentido, supomos, a partir de um olhar certeauniano (1998), que esses modos de usos escolares que foram feitos desses impressos de destinação pedagógica (CARVALHO, 1998) põem em voga procedimentos adotados pelos professores, que de 
certa forma obedeciam a regras impostas pelo sistema educacional, porém (re)inventavam maneiras de agir para atender de algum modo à realidade vivida no seu contexto naquele espaço/tempo. Assim, entendemos que houve resistências, contradições e imposições que atravessaram as apropriações de professores em relação aos materiais e métodos de ensino da leitura no município de Santa Teresa (ES) na década de 1960.

A ata de reunião pedagógica das Escolas Reunidas "Patrimônio de Santo Antonio", do ano de 1966, traz o registro que materializa a voz da Supervisora com a determinação do uso do livro destinado ao ensino inicial da leitura: “[...]. Logo a seguir, mostrou qual seria o livro adotado para o $1^{\circ}$ ano. O livro de Lili" (ESCOLAS REUNIDAS DE PATRIMÔNIO DE "SANTO ANTÔNIO", 1966, p. 5 (verso); 6). Esse registro comprova que O Livro de Lili foi um dos materiais que circularam nas escolas de ensino primário teresense. Essa prescrição feita por agentes responsáveis pela política educacional sugere uma possível imposição para o uso do material, assim como a defesa pelo método analítico, no entanto, não tivemos acesso a cadernos de alunos que contemplassem atividades referentes ao conteúdo desse material.

O Livro de Lili foi elaborado por Anita Fonseca sob a orientação da professora Lúcia Casasanta em 1932. O pré-livro, resultado de um concurso coordenado por Casasanta, foi editado oficialmente em 1940, pela Livraria Francisco Alves, e reeditado a partir dos anos 50 pela Editora do Brasil S/A. Esse livro trazia o manual do professor separado do livro do aluno, assim como a presença de características próprias do Método Global de Contos em sua proposta de ensino. O pré-livro era acompanhado de materiais suplementares como os cartazes para o uso do professor em sala de aula e um caderno com fichas para trabalhar as lições. Cabe ressaltar ainda que, diferentemente da tradicional cartilha, o livro do aluno ia sendo composto ao longo do processo de alfabetização. A figura 20 traz a ilustração da capa da edição de 1961. 


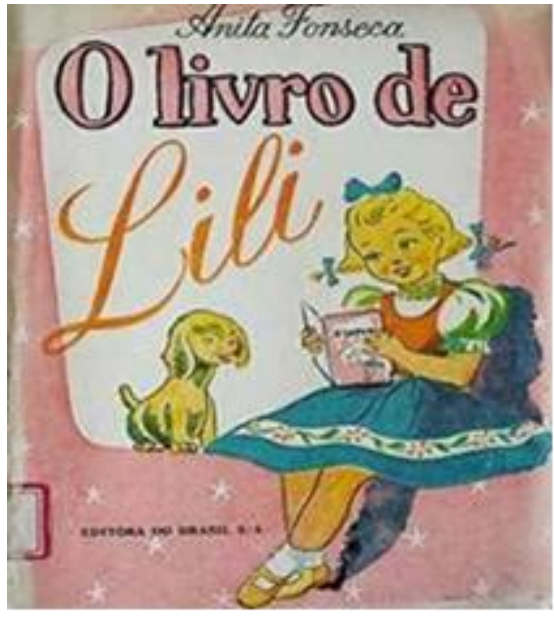

Autor: FONSECA, Anita

Título: O Livro de Lili (cartilha)

Editora: Editora do Brasil S/A

Ano: 1961

Edição: $87 .^{\circ}$

Outras informações:

Figura 20: Capa da cartilha O Livro de Lili Fonte: 0 Livro de Lili, Anita Fonseca, 1961.

Vale ressaltar que o Método Global de Contos foi discutido por Maciel (2001, p. 121), que apresenta uma visão do processo de alfabetização iniciado por meio desse método que

[...] tem como principal característica iniciar o processo de alfabetização por textos com sentido completo, por um todo, isto é, por frases ligadas pelo sentido, formando um enredo, constituindo uma unidade de leitura. Para atender a essa característica, a historieta ou conto deveria ser sobre um tema estimulador e de acordo com os interesses infantis: vida familiar, brinquedos, aventuras reais e maravilhosas com outras crianças, etc.

Maciel (2001, p. 143) afirma que Anita Fonseca “[...] enfatiza os valores psicopedagógicos do método global ou analítico, e justifica a sua opção pelo 'método global' em detrimento do 'sintético"'. A edição publicada no ano de 1961 tem por finalidade ilustrar na primeira lição, intitulada Lili, a proposta de trabalho para o ensino da leitura. Conforme mostram as figuras a seguir: 


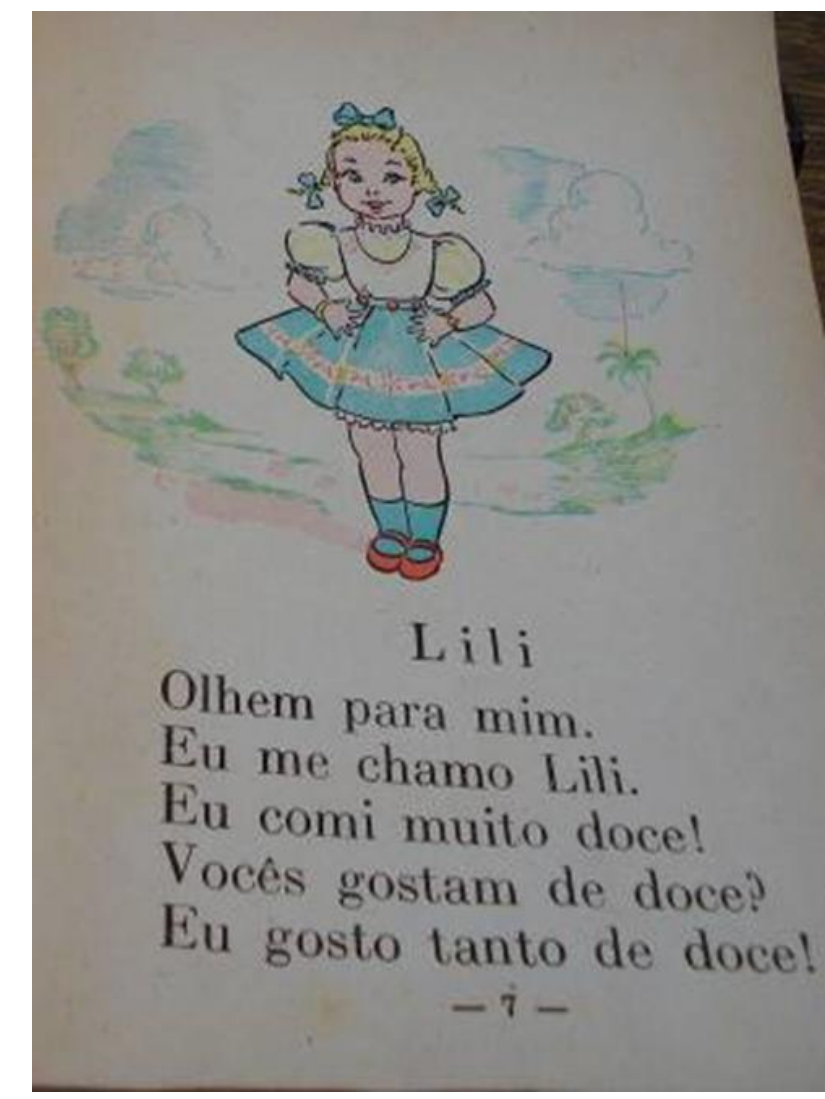

Figura 21: Primeira lição de O Livro de Lili, p. 7 em letra de imprensa.

Fonte: O Livro de Lili, Anita Fonseca, 1961.

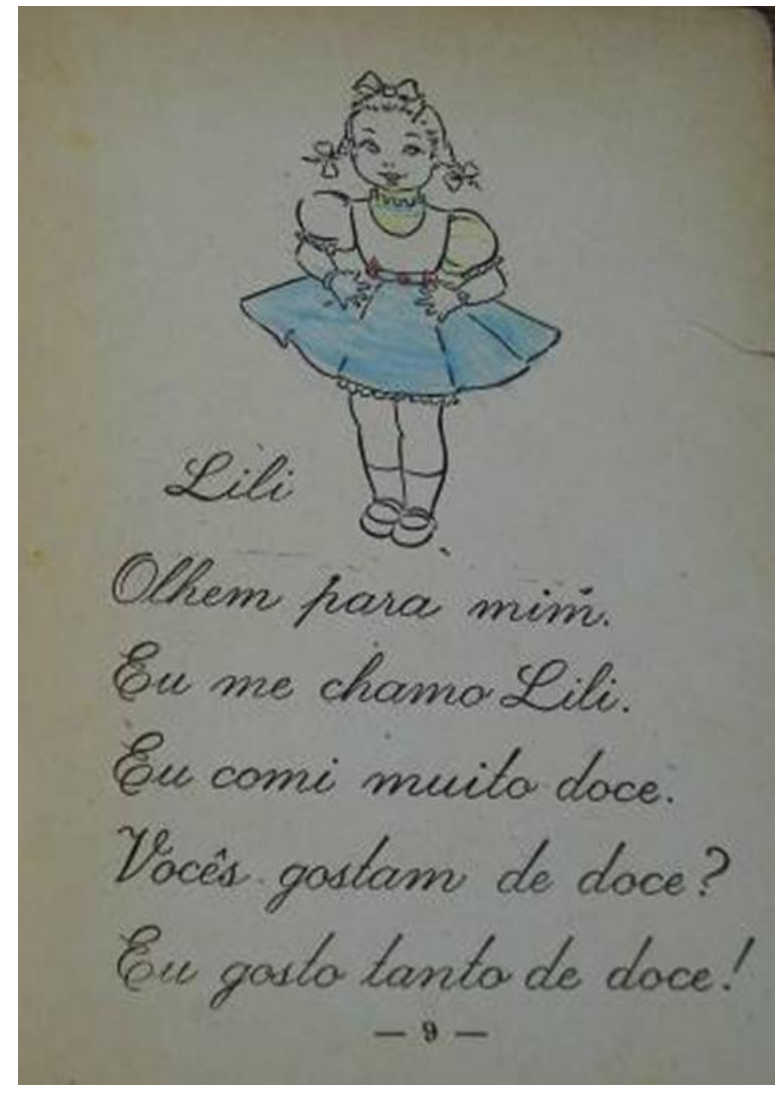

Figura 22: Primeira lição de O Livro de Lili, p. 9 em letra cursiva.

Fonte: O Livro de Lili, Anita Fonseca, 1961.

O Livro de Lili, composto de historietas com cinco a sete sentenças cada, apresentava as suas lições iniciais em letras de imprensa e em letra cursiva seguidas de atividades sob a forma de fichas compostas das sentenças, das palavras e das sílabas referentes ao texto, não recomendando o reconhecimento das vogais e das consoantes em nenhum momento do processo de ensino da leitura.

Tomando como referência a primeira lição do livro, averiguamos que ao contrário do método sintético "[...] em que o aluno recebe desde o começo do processo de alfabetização a cartilha destacando as sílabas a serem apreendidas e aprendidas" (MACIEL, 2001, p. 121), no Método Global de Contos “[...] inicia-se o processo do todo para as partes, seguindo-se a decomposição do texto em sentenças, palavras, sílabas" (MACIEL, 2001, p. 123), conforme pode ser observado nas atividades das lições nas figuras 23, 24 e 25: 


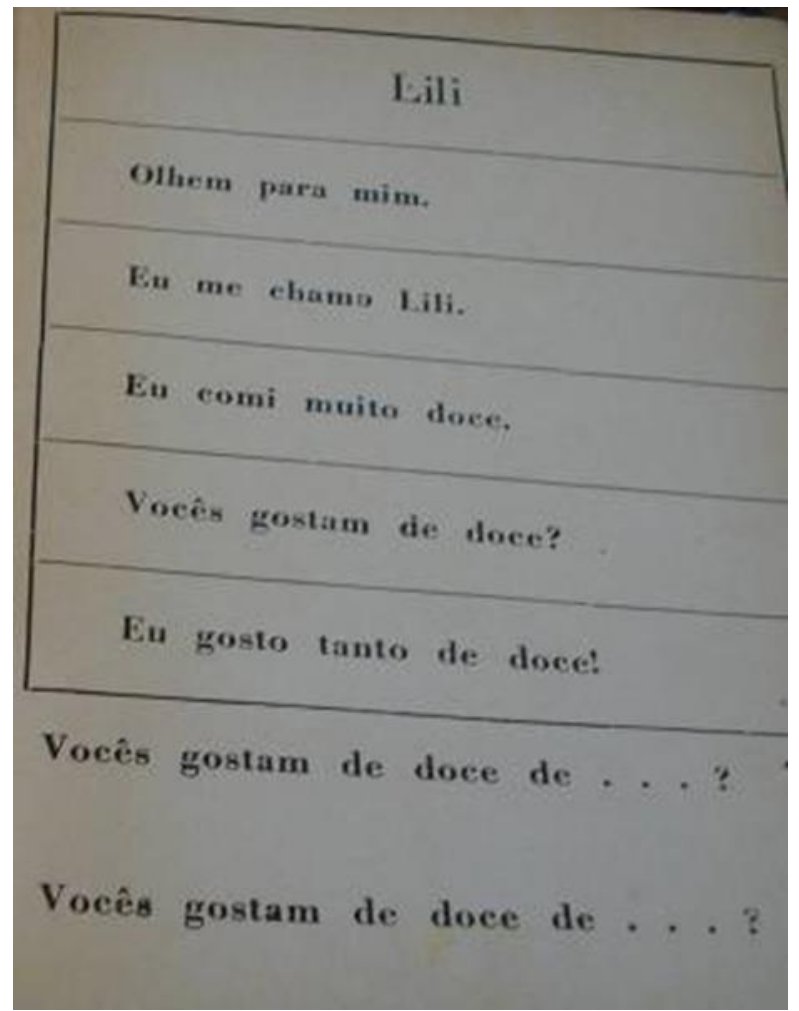

Figura 23: Primeira lição de O Livro de Lili, p. 11. (atividade da lição com fichas de sentenciação).

Fonte: O Livro de Lili, Anita Fonseca, 1961.

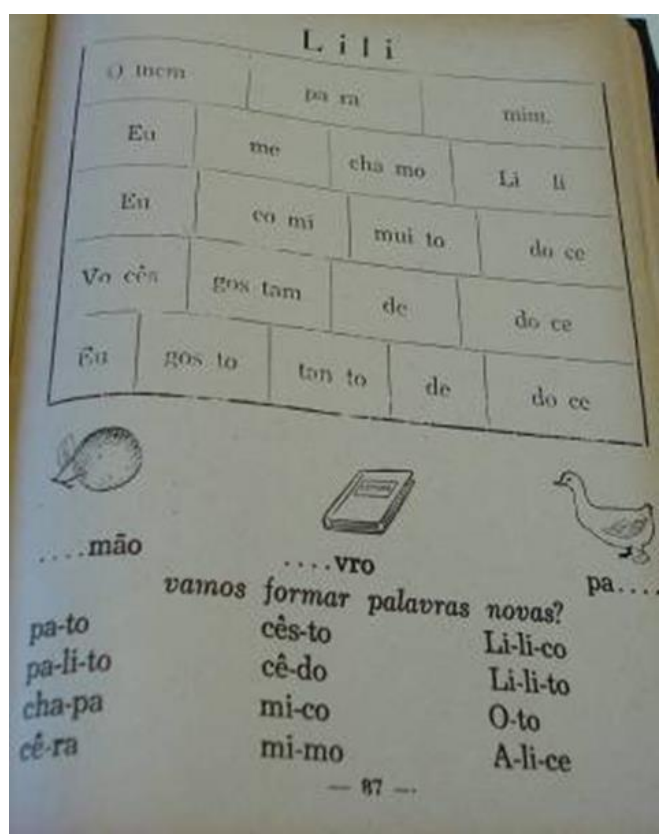

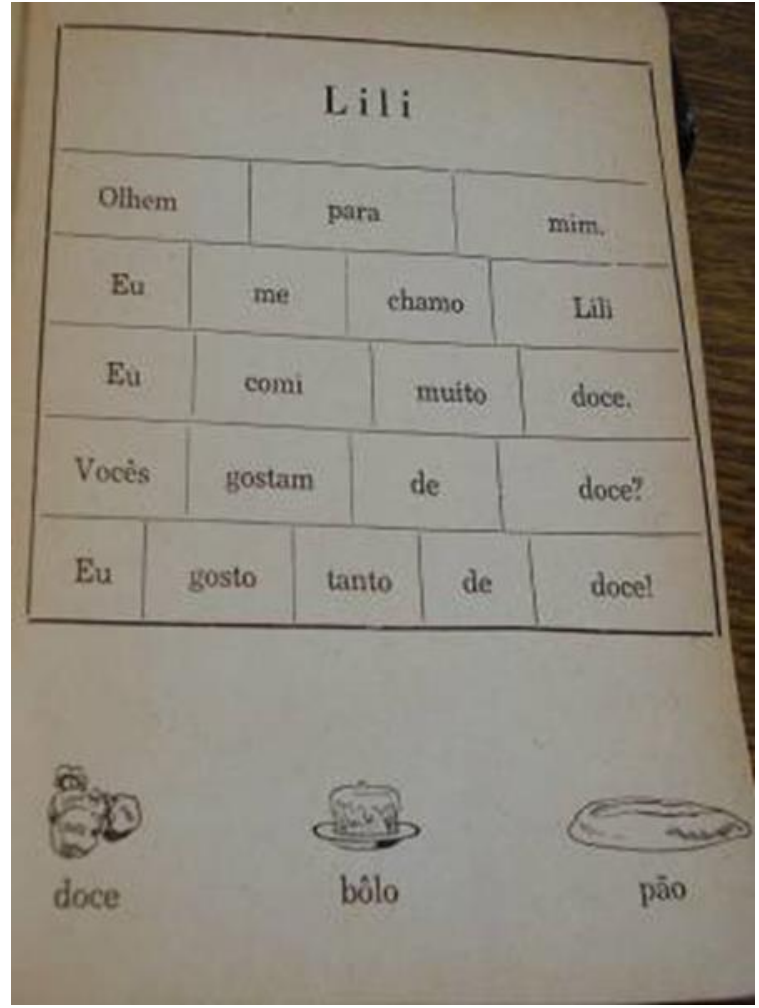

Figura 24: Primeira lição de O Livro de Lili, p. 13. (Atividade da lição com fichas de palavração). Fonte: O Livro de Lili, Anita Fonseca, 1961.

Figura 25: Primeira lição de O Livro de Lili, p. 87. (Atividade da lição com fichas de silabação). Fonte: O Livro de Lili, Anita Fonseca, 1961.

As atividades registradas nas provas parciais e finais de alunos da escola primária teresense da década de 1960 representavam e materializavam as apropriações por parte 
dos professores de materiais didáticos para o ensino da leitura. Esses registros permitiram revelar o uso de livros que circularam naquela época, como o livro Infância Brasileira para a primeira série primária. Essa constatação foi possível através da atividade de ditado referente ao texto da primeira lição do livro, página 11, presente no caderno de aluna, conforme indicam as figuras 26 e 27.

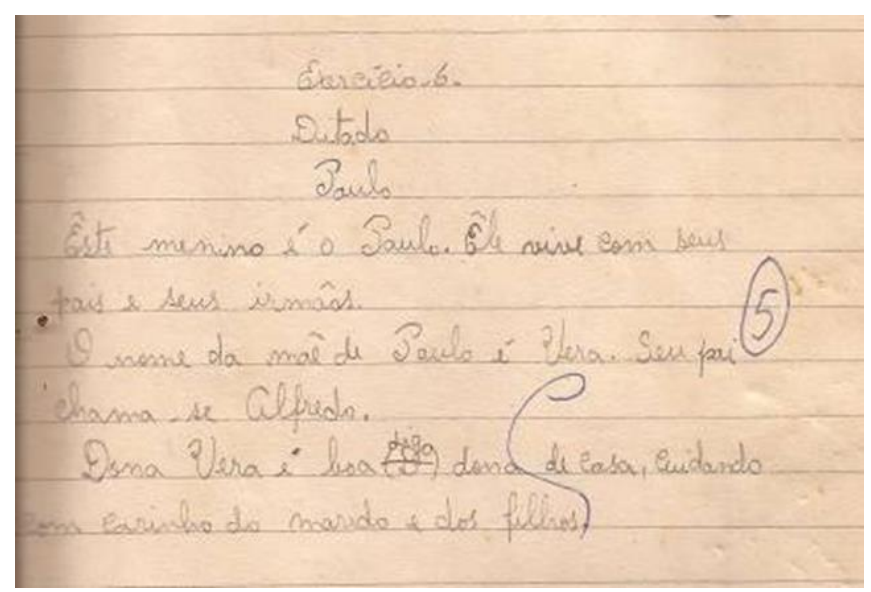

Figura 26: Fragmento da prova de Língua Vernácula da aluna do Quarto ano da Escola Singular "Fazenda Orlando Moschem", 1967.

Fonte: Arquivo pessoal de Maria da Silva.

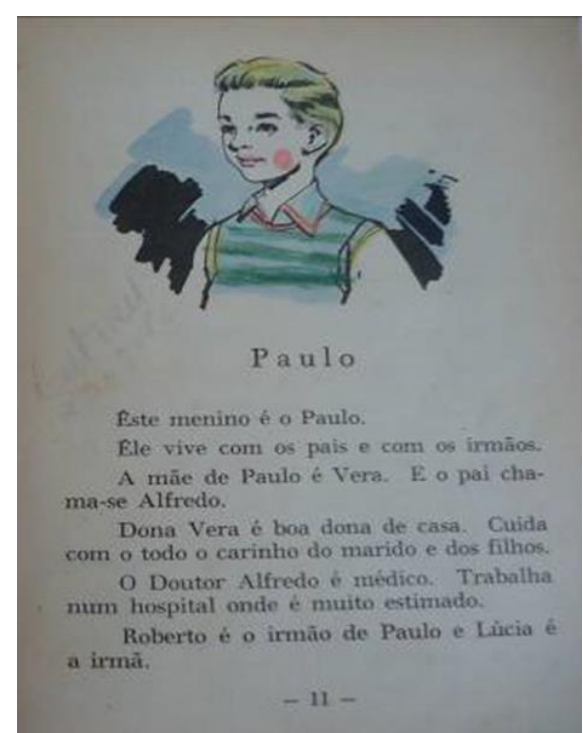

Figura 27: Fragmento do livro Infância Brasileira ( $1^{\text {a }}$ Série).

Fonte: Arquivo pessoal da autora.

Apesar de esse livro ser destinado a alunos da primeira série primária cujos alunos fossem alfabetizados, a atividade de ditado realizada em uma prova parcial na Escola Singular "Orlando Moschem", em 1967, foi feita por uma aluna que cursava a quarta série primária. Esse fato nos indicia apropriação dos materiais de alfabetização em turmas mais avançadas na escola primária teresense nesse período.

Ariosto Espinheira, autor do livro, era educador ligado ao movimento escolanovista e publicou também o mesmo título para a $2^{\mathrm{a}}$, a $3^{\mathrm{a}}$ e a $4^{\mathrm{a}}$ séries primárias. $\mathrm{O}$ livro destinado à $1^{\text {a }}$ Série Primária se encontra dividido em linguagem, com atividades de leitura silenciosa, escrita e gramática, e em conhecimentos gerais, abordando conteúdos de história do Brasil, ciências naturais, geografia e matemática. 


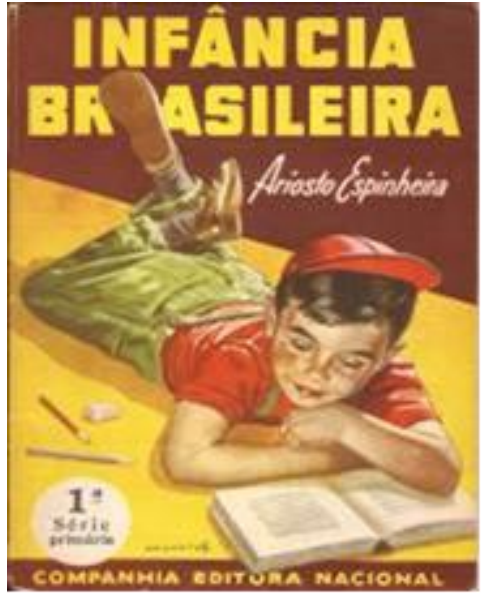

Figura 28: Capa do livro Infância Brasileira

Fonte: Arquivo pessoal da autora.
Autor: ESPINHEIRA, Ariosto

Editora: Cia. Editora Nacional

Título: Infância Brasileira

Ano: 1965

Edição $271 .^{a}$

Outras informações: O livro destina-se para a primeira série primária e contém conhecimentos de: linguagem, história do Brasil, geografia, ciências naturais, matemática.

O livro Infância Brasileira, de autoria de Ariosto Espinheira, traz estampada na capa a figura de um menino de aparência saudável, pele clara e corada. Conforme análise realizada por Falcão (2010), a criança que ocupa lugar de destaque na capa sugere o discurso pedagógico em voga na década, quando o ideário da Escola Nova tinha em seu fundamento o "puericentrismo", ou seja, a criança no centro do processo educativo.

O uso desse livro pelo professor na Escola Singular "Orlando Moschen", com alunos de série avançada, sinaliza táticas utilizadas no intuito de atender às exigências impostas pelo sistema, que entendemos como as representações estratégicas de circulação dos títulos indicados pela política educacional vigente, e as necessidades existentes no interior da escola primária. Assim sendo, “[...] essas maneiras de se reapropriar do sistema produzido, criações de consumidores, visam uma terapêutica de socialidades deterioradas, e usam técnicas de reemprego onde se podem reconhecer os procedimentos das práticas cotidianas" (CERTEAU, 1998, p. 52, grifos do autor).

Outro material que circulou na escola primária de Santa Teresa (ES) na época estudada foi o livro Meus Exercícios, de autoria de Helena Lopes Abranches e Esther Pires Salgado, destinado a $2^{a}$ série; contemplava a área de linguagem, matemática e conhecimentos gerais, conforme capa ilustrada na figura 29: 


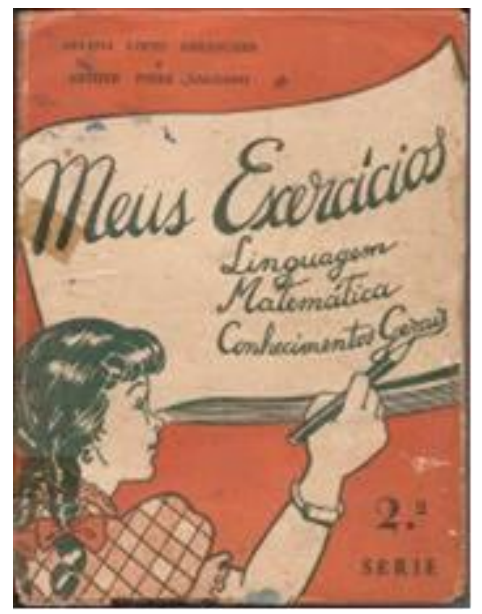

Autor(es): ABRANCHES, Helena Lopes; SALGADO, Esther Pires

Título: Meus exercícios $-2^{\text {a }}$ Série - Linguagem, matemática e conhecimentos Gerais

Editora: Companhia Brasileira de Artes Gráficas

Ano: 1954

Edição: $10^{a}$

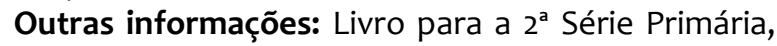
cujo exemplar é da década de 1950, porém manteve o mesmo conteúdo na década de 1960.

Figura 29: Capa do livro Meus Exercícios destinado à

$2^{\mathrm{a}}$ série primária. Fonte: Arquivo pessoal da

pesquisadora Neusa Balbina de Sousa.

O livro, constituído por 193 páginas, dedicou as 103 primeiras páginas à linguagem, sendo as demais destinadas às áreas de matemática e conhecimentos gerais. As atividades que envolveram conhecimentos sobre linguagem se apresentavam sequencialmente em (I) Leitura, redação e cópia; (II) Temas para redação; (III) Cópia e ditado; (IV) Exercícios gramaticais; (V) Leitura silenciosa.

A apropriação das atividades referentes a esse livro ocorreu de forma similar à forma de uso do título Infância Brasileira. Notamos que o exercício indicado pelas autoras como atividade de leitura, redação e cópia foi encontrada no caderno de uma aluna da Escola Singular “Baixo Santa Júlia”. A imagem desse caderno comprova a apropriação desse material com um uso divergente do indicado, pois a atividade foi realizada por uma aluna do $4^{\circ}$ ano primário e sob a forma de ditado, conforme apresentado nas figuras $30 \mathrm{e}$ 31.

Para Frade (2007), a leitura silenciosa esteve intimamente relacionada a atividades empreendidas pelo método analítico do ensino da leitura, quando era privilegiado o sentido da visão em detrimento do sentido do ouvido nos métodos sintéticos. Considerando que, na década de 1960, o discurso das políticas educacionais clamava pelo uso dos métodos analíticos, a prática da leitura silenciosa era entendida como a mais adequada. No entanto, percebemos uma apropriação feita pelo professor que privilegiou o método sintético e não condizente com o pensamento renovador vigente. 


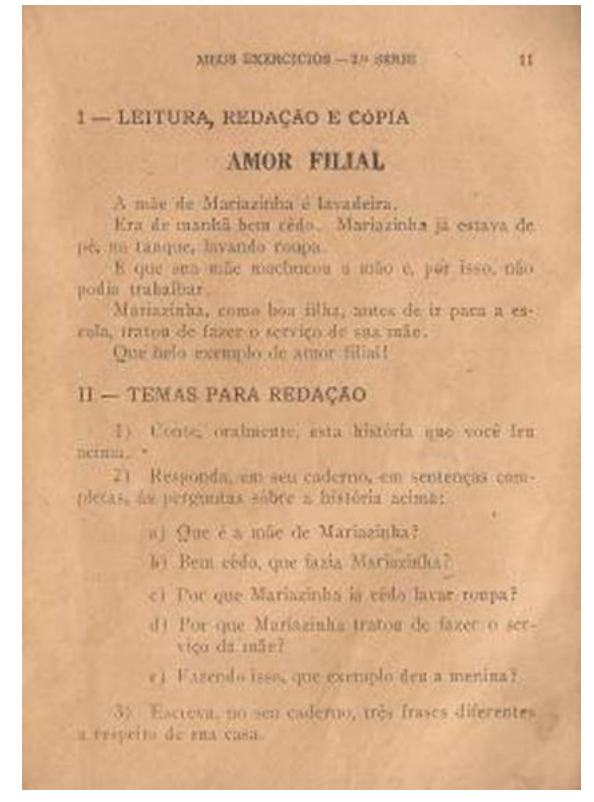

Figura 30: Página 11 do livro Meus Exercícios Fonte: Arquivo pessoal Neusa Balbina de Sousa.

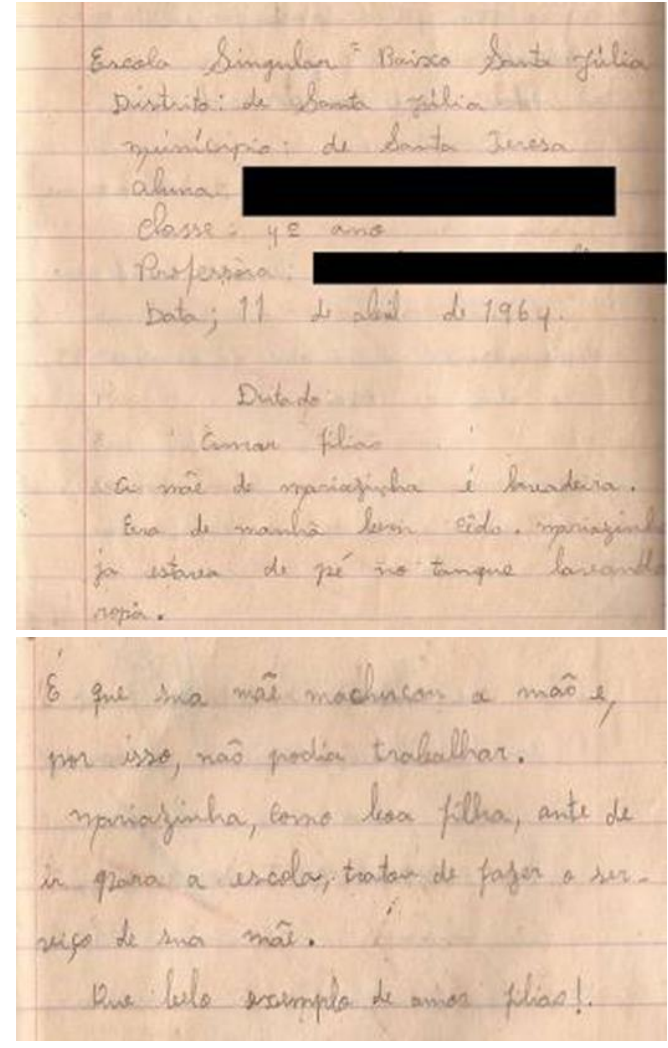

Figura 31: Fragmento do caderno da aluna do quarto ano primário da Escola Singular "Baixo Santa

Júlia" Atividade realizada em 11/04/1964

Fonte: Arquivo pessoal de Maria de Lurdes Milli.

Nas atas de reuniões pedagógicas das Escolas Reunidas de "São Roque" (1965), do Grupo Escolar “Almirante Tamandaré” (1967) e do Grupo Escolar “Visconde de Inhaúma” (1969), podemos observar que, mesmo com o discurso de renovação da escola primária, permaneceram ao longo da década de 1960 procedimentos didáticos já consolidados em décadas anteriores. Essas práticas foram respaldadas por orientações dos agentes educacionais aos professores da escola primária de Santa Teresa (ES) em relação à leitura e, especificamente, às instruções para prova de leitura oral:

Terminando a professôra [...] de expor o seu tema, usou da palavra a Sra. Diretora. Leu as instruções referentes à prova de leitura oral [...]. (ESCOLAS REUNIDAS DE "SÃO ROQUE, 1965, p. 15 (verso))

A Diretora iniciou a reunião falando sôbre a Prova de Leitura Oral para o $1^{\circ}$ ano afirmando que a mesma não reprovaria nenhum aluno. Explicou às professôras do $1^{\circ}$ ano que não deveriam deixar fazer a prova de leitura oral os alunos que não sabiam ler considerando-os analfabetos. Leu uma 
circular a qual trazia a explicação correta de como proceder durante a aplicação da prova de leitura oral para $01^{\circ}$ ano e como atribuir a nota exata. (GRUPO ESCOLAR “ALMIRANTE TAMANDARÉ”, 1967, p. 23 (verso))

Em seguida a Supervisora [...] apresentou um excelente plano de leitura e nos disse que devemos ter em mente os objetivos principais como desenvolvimento de vocabulário, de velocidade de leitura, leitura oral correta, desenvolver habilidades de estudos, gôsto e interêsse pelas leituras e tudo isto dependerá de um planejamento bem feito pela professôra, procurando incentivar a criança durante tôda a leitura. (GRUPO ESCOLAR “VISCONDE DE INHAÚMA”, 1969, p. 26 (verso)-27)

Os registros acima expressam discursos conflitantes, em se tratando dos princípios que fundamentavam as práticas de ensino da leitura. Os trechos indiciam a apropriação da prática de leitura oral com atenção especial à função avaliativa da leitura em relação ao desempenho dos alunos. Esse fato revela a forma de pensar a leitura na escola primária teresense na década em investigação e deixa perceptível que o trabalho visava à aquisição de fluência da leitura, mantendo a prática de recitação nos exercícios escolares (BATISTA; GALVÃO; KLINKE, 2002), aproximando-se de princípios que orientaram os métodos sintéticos.

Essas apropriações permaneciam agregadas às maneiras de ensinar a leitura em momentos anteriores ao pensamento renovador, conforme pontuam Batista; Galvão; Klinke (2002, p. 45).

A leitura em voz alta era considerada, assim, até as primeiras décadas do século XX, a mais adequada ao ensino. Através da oralidade, característica predominante de diversas dimensões da vida brasileira na época, os professores deveriam incentivar a leitura dos alunos e, ao mesmo tempo, proporcionar-Ihes um bom desenvolvimento social e intelectual.

Desse modo, percebemos que diferentes formas de ensinar a leitura ganharam vida autônoma nas rotinas escolares de professores da escola primária teresense, fazendo valer uma tensão entre o que era prescrito e o que era praticado. 


\section{Considerações Finais}

A análise das fontes documentais nos permitiu inferir que professores primários do município de Santa Teresa (ES) na década de 1960 se apropriavam de diferentes materiais e métodos por meio do uso de cartilhas, pré-livros e livros destinados à aprendizagem inicial da leitura, que desvelaram práticas de ensino que articularam princípios e métodos distintos a fim de atender às necessidades da escola primária.

Desse modo, percebemos um distanciamento entre o discurso emanado de um órgão do Estado e a concretização do projeto educacional pretendido, uma vez que a proeminência em defesa dos métodos analíticos, com ênfase para o uso do método global de ensino, não impedia o uso de métodos sintéticos nas práticas cotidianas dos professores primários. Assim, percebemos que outras maneiras de ensinar a leitura, bem como a escrita, resistiram e ganharam vida autônoma na rotina dos professores em escolas primárias teresenses.

\section{Referências}

ABRANCHES, Helena Lopes; SALGADO, Esther Pires. Meus exercícios: $2^{\mathrm{a}}$ série - linguagem, matemática e conhecimentos gerais. Rio de Janeiro: Companhia Brasileira de Artes Gráficas, 1954.

AMOROSO, Cecília Bueno dos Reis. Onde está o patinho? São Paulo: Edições Melhoramentos, [19--].

BATISTA, Antônio Augusto Gomes; GALVÃO, Ana Maria de Oliveira; KLINKE Karina. Livros escolares de leitura: uma morfologia (1866-1956). Revista Brasileira de Educação. Rio de Janeiro, n. 20, maio/ago., 2002. Disponível em:

<http://www.anped.org.br/rbe/rbedigital/rbde20/rbde20_04_antonio__ana_maria_e_karina.pdf>. Acesso em: 29 out. 2012.

CARVALHO, Marta Maria Chagas de. Por uma história cultural dos saberes pedagógicos. 
In: CARVALHO, Marta Maria Chagas de. Práticas educativas, culturas escolares, profissão docente: atas [do] 2. Congresso ..., São Paulo: Escrituras, 1998. p. 31-40.

CERTEAU, Michel de. A invenção do cotidiano: 1. artes de fazer. 12. ed. Petrópolis, RJ: Vozes, 1998.

CHARTIER, Roger. A história cultural: entre práticas e representações. 2. ed. Algés, Portugal: DIFEL, 2002.

ESCOLAS REUNIDAS DE “SÃO ROQUE”. Ata da 4 a Reunião Pedagógica. Santa Teresa, ES, 20 nov. 1965.

ESCOLAS REUNIDAS “PATRIMÔNIO DE SANTO ANTÔNIO”. Ata da $\mathbf{2}^{\mathbf{a}}$ Reunião

Pedagógica. Santa Teresa-ES, $1^{\circ}$ abr. 1966.

ESPINHEIRA, Ariosto. Infância brasileira: para a primeira série primária. 271.ed. São Paulo: Companhia Editora Nacional, 1965.

FALCÃO, Elis Beatriz de Lima. História do ensino da leitura no Espírito Santo (1946-1960). 210, 280f. Dissertação (Mestrado em Educação) - Universidade Federal do Espírito Santo, Vitória, 2010. .

FONSECA, Anita. O livro de Lili (cartilha). 87. ed. São Paulo: Editôra do Brasil S/A, 1961.

FRADE, Isabel Cristina Alves da Silva. Métodos de alfabetização, métodos de ensino e conteúdos da alfabetização: perspectivas históricas e desafios atuais. Revista Educação Santa Maria, v. 32, n. 01, p. 21-40, 2007. Disponível em: <http://www.ufsm.br/ce/revista>. Acesso em: 20 jan. 2012.

GOMES, Silvia Cunha. A alfabetização na história da educação do Espírito Santo no período de 1924 a 1938. 2008,209f. Dissertação (Mestrado em Educação) - Universidade Federal do Espírito Santo, Vitória, 2008.

GRUPO ESCOLAR “ALMIRANTE TAMANDARÉ”. Ata da 5 a Reunião Pedagógica. Santa Teresa-ES, 18 nov. 1967.

GRUPO ESCOLAR “VISCONDE DE INHAÚMA”. Ata da Reunião Pedagógica. Santa TeresaES, 29 mai. 1969.

JULIA, Dominique. A cultura escolar como objeto histórico. Revista Brasileira de História da Educação. Tradução de Gizele de Souza. Campinas, v. 1, n. 1, jan./jun. 2001. Disponível em:<http://www.rbhe.sbhe.org.br/index.php/rbhe/article/view/273/281>. Acesso em: 20 abr. 2012.

LEITE, Olivia Pinto de Castro. Exercícios de leitura silenciosa e linguagem: primeiro volume. Belo Horizonte: Editora do Brasil em Minas Gerais S/A. 1967.

LORENÇO FILHO, Manuel Bergström. Cartilha do povo: para ensinar a ler rapidamente. 
586. ed. São Paulo: Edições Melhoramentos, 1940.

MACIEL, Francisca Izabel Pereira Maciel. Lúcia Casasanta e o método global de contos: uma contribuição à história da alfabetização em Minas Gerais. 2001, oof. Tese (Doutorado em Educação) - Universidade Federal de Minas Gerais, Belo Horizonte, 2001.

MORTATTI, Maria do Rosario Longo. Os sentidos da alfabetização: (São Paulo, 18761994). São Paulo: Ed. UNESP: CONPED: INEP, 2000. 372p.

MORTATTI, Maria do Rosario Longo. A “querela dos métodos” de alfabetização no Brasil: contribuições para metodizar o debate. Revista ACOALFAplp: Acolhendo a alfabetização nos Países de Língua portuguesa, São Paulo, ano 3, n. 5, 2008. Disponível em: <http://www.acoalfaplp.net>. Acesso em: 12 dez. 2011.

OLIVEIRA, Mariano de. Cartilha ensino rápido da leitura. 820. ed. São Paulo: Edições Melhoramentos, 1959.

SCHWARTZ, Cleonara Maria. O ensino da leitura e a formação do leitor na escola primária capixaba na década de 1960: relatório científico final de pós-doutorado. Vitória, 2012. Mimeo.

VIDAL, Diana Gonçalves. Culturas escolares: estudo sobre práticas de leitura e escrita na escola pública primária (Brasil e França, final do século XIX). Campinas, SP: Autores Associados, 2005.

VIÑAO, Antonio. Os cadernos escolares como fonte histórica: aspectos metodológicos e historiográficos. In: MIGNOT, Ana Chrystina Venancio (Org.). Cadernos à vista: escola, memória e cultura escrita. Rio de Janeiro: EdUERJ, 2008. p. 15-33.

Universidade do Estado de Santa Catarina - UDESC

Programa de Pós-Graduação em Educação - PPGE

Revista Linhas

Volume 16 - Número 32 - Ano 2015

revistalinhas@gmail.com 